\title{
Dysregulation of Wnt Signaling in Breast Cancer
}

\author{
Taj D. King and Yonghe Li \\ Department of Biochemistry and Molecular Biology \\ Drug Discovery Division \\ Southern Research Institute \\ Birmingham, $A L$ \\ USA
}

\section{Introduction}

The Wnt signaling pathway is a significant pathway that consists of two sub-categories: (1) the canonical Wnt/ $\beta$-catenin signaling pathway and (2) the non-canonical Wnt signaling pathway. A well-programmed crosstalk exists between canonical and non-canonical Wnt pathways, which enable them to regulate stem cell renewal, cell proliferation, migration, and differentiation. Wnt signals are transduced via the interaction between cell surface receptors and secreted Wnt ligands and Wnt agonists, which subsequently activate downstream proteins that regulate cytoskeletal rearrangement, transcription, and cell cycle. Aberrant Wnt signaling is involved in the development of a variety of cancers, including breast cancer. Breast cancer is the most invasive form of cancer in women and is the second leading cause of death in women in industrialized nations. Three distinct biomarkers including the estrogen receptor (ER), progesterone receptor (PR), and the human epidermal growth factor receptor 2 (HER-2) are used to determine breast cancer therapy (Nguyen et al., 2010). AntiER and HER2 therapies have benefitted a subset of breast cancer patients (Carter et al., 1992; Arteaga, 2003). However, the genetic diversity of this disease varies greatly in that the pathological hallmarks are distinct in each case. Recent discoveries in stem cell research have shown that breast cancer stem cells may be responsible for the aggressiveness of some breast cancers and may contribute to their resistance to chemotherapy and radiation treatment (Diehn et al., 2009; Li et al., 2008b). Wnt signaling is important in stem cell biology and can lead to tumor formation when aberrantly activated. Therefore, it is essential to understand the intrinsic mechanisms of the Wnt signaling pathway to elucidate candidate proteins within this pathway that may serve as potential targets for breast cancer therapy.

\section{The Wnt signaling pathways}

At the heart of the canonical Wnt pathway is the stabilization of cytosolic $\beta$-catenin, which enters the nucleus and activates Wnt target genes by binding to transcription factors of the T-cell factor and the lymphoid enhancing factor (TCF/LEF) family (Kohn and Moon, 2005; McDonald et al., 2009). Wnts are secreted glycoproteins that can bind to low-density lipoprotein receptor-related protein 5 (LRP5) or LRP6 and seven transmembrane receptors 
of the Frizzled (Fz) family. In the absence of Wnt ligands, $\beta$-catenin is phosphorylated by a multi-protein complex that marks it for ubiquitination and degradation by the proteasome (Fig. 1A). This $\beta$-catenin degradation complex contains the adenomatous polyposis coli (APC) tumor suppressor, the scaffold protein Axin, the glycogen synthase kinase $3 \beta$ $(\mathrm{GSK} 3 \beta)$, and the casein kinase 1 (Ck1). The action of this complex is inhibited upon binding of Wnt to its receptors (Fig. 1B). A variety of Wnt/ $\beta$-catenin target genes have been identified, which include those that regulate cell proliferation, embryonic developmental and tumor progression (Kohn and Moon, 2005; McDonald et al., 2009).
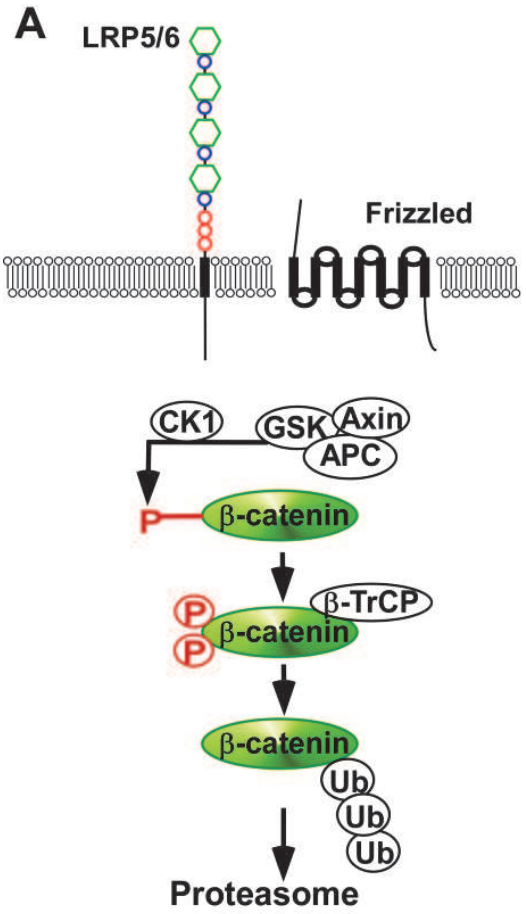
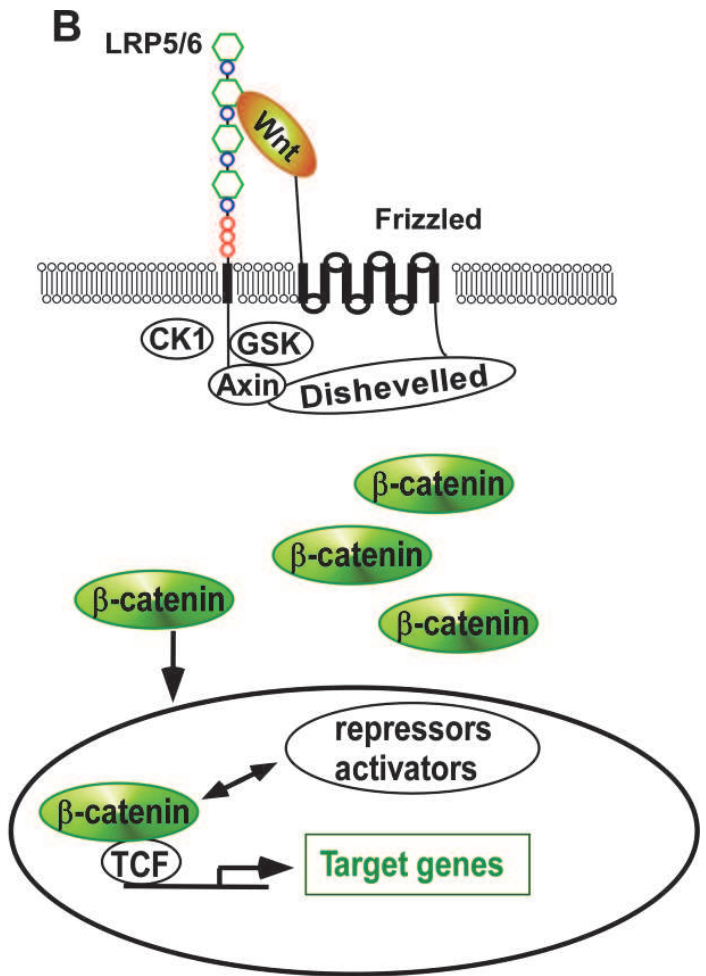

Fig. 1. The canonical Wnt signaling cascade, simplified. (A) In the absence of interaction between Wnts and receptors, $\beta$-catenin levels are efficiently regulated by a complex containing APC, axin, and GSK3 $\beta$. This complex promotes phosphorylation of $\beta$-catenin by $\mathrm{Ck} 1$ and GSK3 $\beta$. Phosphorylated $\beta$-catenin becomes multi-ubiquitinated $(\mathrm{Ub})$ and subsequently degraded by the $26 \mathrm{~S}$ proteasome. (B) In the presence of Wnts, phosphorylation and degradation of $\beta$-catenin are blocked which allows the association of $\beta$-catenin with TCF transcription factors. The TCF: $\beta$-catenin complexes bind to DNA and activate Wnt target genes together with various transcriptional repressors or activators.

The non-canonical Wnt signaling pathway, which operates independently of downstream $\beta$ catenin activation, consists of the Wnt/ $\mathrm{Ca}^{2+}$, Wnt/Planar Cell Polarity (PCP), and Wnt/ROR2 pathway. There are several excellent reviews that discuss the non-canonical Wnt signaling pathway extensively (Kohn and Moon, 2005; Siefert and Mlodzik, 2007; Wang and Nathans, 
2007b; Schulte, 2010). The Wnt/ $\mathrm{Ca}^{2+}$ and the Wnt/PCP pathways are activated via the interaction of Wnt5a and Wnt11 with their Fz co-receptor. This interaction elicits downstream increases in intracellular $\mathrm{Ca}^{2+}$ flux $\left(\mathrm{Wnt} / \mathrm{Ca}^{2+}\right)$ and Dishevelled (Dvl)-mediated downstream activation of Rac, Rho, and Jun N-terminal kinase (Wnt/PCP), which ultimately regulate cell motility and orientation. The Wnt/ROR2 pathway requires the interaction of Wnt-5a with ROR2, which activates downstream signaling events that regulate cell motility. Some noncanonical Wnt signaling pathways, including the Wnt/ $\mathrm{Ca}^{2+}$ and the Wnt/ROR2 pathways, antagonize canonical Wnt signaling (discussed in more detail below).

\subsection{Wnt receptors frizzled protein and LRP5/6}

The frizzled (Fz) gene product, originally discovered in D. melanogaster, is required for the development of cuticle wing hairs (Vinson and Adler, 1987; Vinson et al., 1989). The Fz receptor consists of 10 mammalian isoforms that contain an $\mathrm{N}$-terminal signal peptide, an extracellular cysteine-rich domain (CRD), a seven-pass transmembrane domain, and an intracellular C-terminal domain, which contains the KTxxxW motif. The CRD of the Fz receptor interacts with the homologous CRD of Wnt proteins (Schulte, 2010). The Fz receptor also interacts with R-spondin (Kazanankaya et al., 2004; Kim et al., 2005; Nam et al., 2006; Wei et al., 2007), Norrin (Smallwood et al., 2007), and secreted frizzled-related proteins (Rattner et al., 1997; Kawano and Kypta, 2003; Bafico et al., 1999). The Fz receptor transduces Wnt signals in a solitary manner or through collaboration with other co-receptors. The Fz receptor forms a ternary complex with Wnt and LRP5/6 to activate the canonical Wnt signaling pathway, which activates $\beta$-catenin transcriptional activity (Tamai et al., 2000; Wehrli et al., 2000).

Experiments performed in Drosophila (Wehrli et al., 2000), Xenopus (Tamai et al., 2000) and mice (Pinson et al., 2000) demonstrated that LRP5/6 (termed Arrow in Drosophila) acts as a co-receptor for Wnts, which interact with both $\mathrm{Fz}$ and LRP5/ 6 to activate the canonical Wnt signaling pathway. LRP5/ 6 appears to transduce the Wnt/ $\beta$-catenin signal by binding and recruiting Axin to the cell membrane (Mao et al., 2001a; Tolwinski et al., 2003; Liu et al., 2003; Tamai et al., 2004). It has been demonstrated that a PPSPXS motif, which is reiterated five times in the LRP6 intracellular domain and is conserved between LRP5, LRP6, and their Drosophila homolog, Arrow, is sequentially phosphorylated by GSK3 $\beta$ and CK1 upon Wnt stimulation (Tamai et al., 2004, Brennan et al., 2004; Zeng et al., 2005; Davidson et al., 2005). Phosphorylation of the PPSPXS motif provides a docking site for Axin binding (Tamai et al., 2004; Brennan et al., 2004; Zeng et al., 2005; Davidson et al., 2005).

LRP5 and LRP6 are two members of the expanding low density lipoprotein receptor (LDLR) family. The mesoderm development protein (Mesd) and the receptor associated protein (RAP) are two specialized molecular chaperones for members of the LDLR family. Mesd is particularly important for the Wnt co-receptors LRP5 and LRP6, while RAP is critical for other members of the LDLR family such as LRP1 and LRP2 (Culi and Mann, 2003; Hsieh et al., 2003; Culi et al., 2004; Li et al., 2005c; Koduri et al., 2007; Li et al., 2006a). Mesd was discovered due to its requirement for the folding of LRP5 and LRP6 (Culi and Mann, 2003; Hsieh et al., 2003). In mice, the consequences of Mesd deficiency resemble what is seen in Wnt3-deficient mutants (Hsieh et al., 2003). Similar to other ER chaperones, Mesd also carries an endoplasmic reticulum (ER) retention signal (KDEL in Drosophila, REDL in mammals) at its carboxyl terminus and localizes to the ER (Culi and Mann, 2003). All members of the LDLR family have at least one six-bladed $\beta$-propeller domain, which is followed by an epidermal growth factor (EGF) repeat (Bu, 2009). Mesd is specifically 
required for the maturation of these $\beta$-propeller/EGF modules through the secretory pathway (Culi et al., 2004). In the absence of Mesd, LRP5 and LRP6 form aggregates in the ER and fail to reach the cell surface (Culi and Mann, 2003; Hsieh et al., 2003; Culi et al., 2004; Li et al., 2005c; Koduri et al., 2007; Li et al., 2006a).

LRP5/ 6 does not contain CRD domains, but Wnt binds to their $\beta$-propeller domains, which are sufficient to transduce Wnt signals (Hey et al., 1998; Liu et al., 2009; Bourhis et al., 2010). Although controversial, the receptor tyrosine kinase-like orphan receptors, ROR1/2 and RYK, can autonomously transduce Wnt signals or serve as co-receptors with Fz to transduce Wnt signals. Similar to the Fz receptor, ROR1/2 possesses a CRD that binds to Wnt proteins, which stimulate receptor dimerization and subsequent activation (Liu et al., 2008; Minami et al., 2010). ROR2 forms a complex with $\mathrm{Fz}$, Wnt, and Cthrci, a Wnt co-factor, to activate the Wnt/Planar Cell Polarity pathway (Yamamoto et al., 2008). Conversely, another study showed that ROR2 cooperates with Fz2 to mediate Wnt-3a-induced $\beta$-catenin activation (Li et al., 2008a). Similar to the ROR1/2 kinase, the RYK tyrosine kinase can form a complex with $\mathrm{Fz}$ and Wnt-3a to activate downstream $\beta$-catenin signaling (Lu et al., 2004) or it can interact with Wnt-5a independent of Fz cooperation to activate non-canonical Wnt signaling (Li et al., 2009). These results suggest that the Fz receptor can act autonomously or in cooperation with other receptors to regulate canonical and non-canonical Wnt signaling pathways.

\subsection{Wnt agonists}

The mammalian proto-oncogene int-1 and its D. melanogaster counterpart, wingless, were discovered prior to the Fz receptors (Nusse and Varmus, 1982; Cabrera et al., 1987; Rijseuijk et al., 1987). The nomenclature was later changed to Wnt, which is an acronym derived from wingless and int-1 (Nusse et al., 1991). Wnts are highly conserved secreted glycoproteins that regulate cell growth and homeostasis in a variety of organ systems. This family of proteins consists of 19 cysteine-rich members that serve as ligands for the Fz receptor (Schulte, 2010). Members of this family can be classified based on their ability to transform epithelial cells. For example, Wnt-1, Wnt-2, Wnt-3, and Wnt-3a are considered to be transforming Wnts; Wnt- 6 and Wnt-7a are weakly transforming Wnts; Wnt- 4 , Wnt-5a, Wnt-5b, and Wnt-7b are non-transforming Wnts (Shimizu et al., 1997). Wnt proteins are palmitoylated (Takada et al., 2006) prior to secretion from the cell via the Wntless/Evi seven-pass transmembrane protein (Banziger et al., 2006; Bartscherer et al., 2006). Following secretion from cells, Wnt proteins interact with the CRD of 10 known mammalian Fz receptors (Schulte, 2010) as well as the extracellular domain of the LRP5/6 receptor (Pinson et al., 2000; Tamai et al., 2000; Wehrli et al., 2000) to activate the canonical Wnt/ $\beta$-catenin signaling pathway. Wnt proteins also activate non-canonical Wnt signaling via their interaction with $\mathrm{Fz}$ (Schulte, 2010), ROR1/2 (Liu et al., 2008; Minami et al., 2010; Li et al., 2008a; Yamamoto et al., 2008), and RYK (Lu et al., 2004; Li et al., 2009). The interaction of Wnt proteins with these receptors enables them to regulate a variety of cellular events including differentiation, proliferation, migration, and tumorigenesis.

\section{R-spondins}

R-spondins (Rspo) are a family of secreted proteins that activate Wnt/ $\beta$-catenin signaling. This family consists of four members (Rspo1-4) that share 40-60\% homology and are structural similar (Kazanskaya et al., 2004). Rspo proteins contain a signal peptide at the Nterminus, which is followed by a highly conserved CRD and a thrombospondin motif. The 
C-terminus is of varying length between the different isoforms of Rspo proteins, but it is positively charged (Kim et al., 2006). Rspo proteins are expressed simultaneously with Wnt proteins during mouse development, suggesting that they may play an important role in facilitating Wnt/ $\beta$-catenin signaling (Nam et al., 2006). The action of Rspo proteins on Wnt/ $\beta$-catenin signaling requires Wnt receptors $\mathrm{Fz}$ and LRP5/6; however, the direct binding between Rspo and LRP5/ 6 is still controversial (Kazanankaya et al., 2004; Kim et al., 2005; Nam et al., 2006; Wei et al., 2007; Li et al. 2010). Furthermore, unlike the Wnt ligands, Rspo proteins do not form a ternary complex with Fz and LRP6 (Nam et al., 2006), suggesting that the mechanistic action of Rspo on Wnt/ $\beta$-catenin signaling activation is not identical to that of Wnt. One plausible mechanism is that Rspo blocks Dkk1-mediated antagonization of Wnt/ $\beta$-catenin signaling by interfering with the interaction of Dkk1 with the Kremen and LRP6 receptors (Kim et al., 2008).
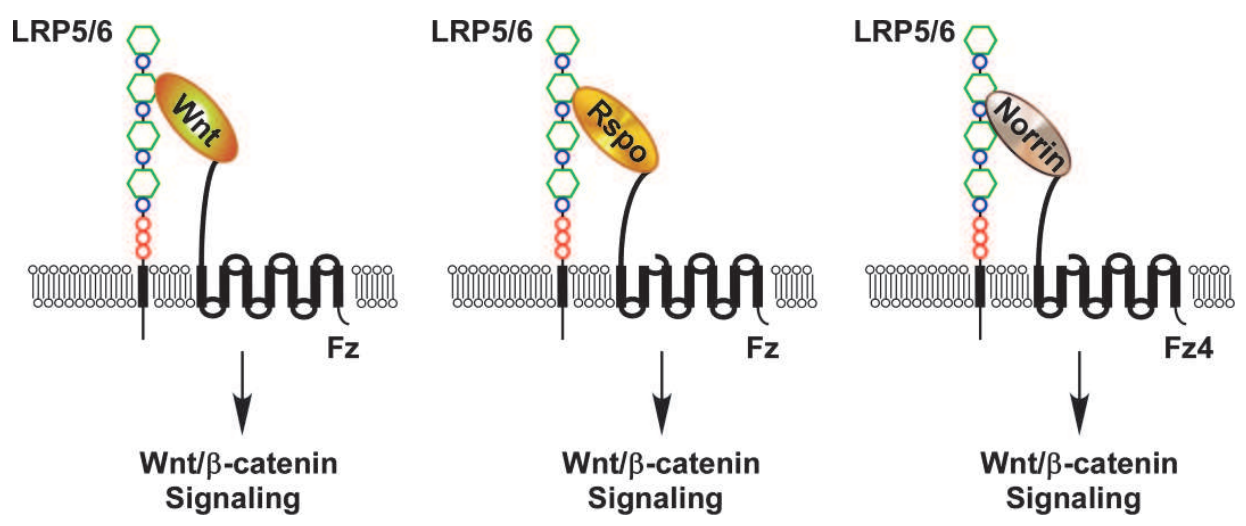

Fig. 2. Secreted Wnt agonists. Wnts are the primary agonists of Wnt/ $\beta$-catenin signaling by binding to LRP5/ 6 and Fz to form a complex with LRP5/ 6 and Fz. Both Rspos and Norrin may act similarly to Wnt, but Norrin specifically binds to Fz4.

\section{Norrin}

Norrie disease is a severe $\mathrm{X}$-linked trait that causes impaired retinal development. The clinical features of this malady include blindness, mental retardation, deafness, microcephaly, and hypogonadism (Hendrickx and Leyns, 2008). Mutations in the Norrie disease protein (Norrin) contribute to the pathology of this disease (Berger et al., 1992; Chen et al., 1992). Norrin specifically interacts with the CRD of Fzd4 and the extracellular domain of LRP5/ 6 receptors, which activates $\mathrm{Wnt} / \beta$-catenin signaling ( $\mathrm{Xu}$ et al., 2004; Smallwood et al., 2007). These findings are interesting because Norrin does not share any structural homology with Wnts (Xu et al., 2004). These results are evident of the diverse and complex nature of the regulation of Wnt signaling to promote development and tumor progression.

\subsubsection{Wnt antagonists}

\section{Dickkopf}

Dickkopf (Dkk; German, big head, stubborn) proteins are a family of secreted glycoproteins that function as regulators of Wnt signaling. Dkks consists of four isoforms in vertebrates 
(Dkk1-4). Dkk1, 2, and 4 contain a Dkk_N domain (also known as CRD1) near the Nterminus and a colipase fold (also known as CRD2) near the C-terminus. Dkk3 also contains a Dkk_N domain, but the N-terminal soggy domain and the C-terminal colipase fold flank the Dkk_N domain (Niehrs, 2006). The colipase fold is necessary for Dkk1, Dkk2, and Dkk4 to inhibit Wnt signaling (Brott and Sokol, 2002; Li et al., 2002; Mao and Niehrs, 2003). The structural divergence of Dkk3 from the other three Dkk family members is a contributing factor to its functional divergence (Glinka et al., 1998; Krupnik et al., 1999; Mao et al., 2001b). Dkk1 functions solely as an inhibitor of canonical Wnt signaling (Glinka et al., 1998). Dkk1 antagonizes Wnt/ $\beta$-catenin signaling by binding directly to the YWTD type $\beta$-propeller domain of LRP6 and prevents Fz-LRP6 complex formation in response to Wnt. Furthermore, Dkk1 interacts with another transmembrane protein, Kremen. The LRP6-Dkk1-Kremen complex is internalized, thus removing LRP6 from the cell surface (Bafico et al., 2001; Mao et al., 2001b; Semenov et al., 2001; Davidson et al., 2002; Mao et al., 2002; Mao and Niehrs, 2003). Dkk2 can activate Wnt/ $\beta$-catenin signaling by interacting with $\mathrm{Fz}$ (Wu et al., 2000) or LRP6 (Brott and Sokol, 2002). Conversely, depending on the cell type, Dkk2 can inhibit WntFz-mediated $\beta$-catenin activation in the absence of LRP5/6 (Wu et al., 2000; Li et al., 2002; Mao and Niehrs, 2003; Caricasole et al., 2003). Furthermore, Dkk2 can inhibit LRP6 mediated $\mathrm{Wnt} / \beta$-catenin signaling in the presence of the Kremen2 receptor by inducing the internalization of LRP6 (Mao and Niehrs, 2003). The dichotomy between Dkk1 and Dkk2 regulation of canonical Wnt signaling is due to the structure and function of the two CRDs of Dkk1 and Dkk2. The colipase fold of Dkk1 and Dkk2 can activate LRP6-mediated $\beta$ catenin activation, and the Dkk_N domain inhibits the action of the colipase fold of Dkk1, but is neutral on Dkk2 (Li et al., 2002; Brott and Sokol, 2002). Therefore, the structural divergence of the Dkk family of proteins enables them to regulate $\mathrm{Wnt} / \beta$-catenin signaling differentially.

\section{Schlerostin}

Schlerosteosis is an autosomal recessive disorder that causes severe skeletal outgrowth in the skull and mandible. Mutations in the schlersotin (SOST) gene, which is located on chromosome 17q11.2, contribute to the pathology of this disease (Balemans et al., 2001; Brunkow et al., 2001). The SOST gene encodes a $24 \mathrm{kDa}$ secreted glycoprotein that contains a cysteine knot-like domain (Balemans et al., 2001; Brunkow et al., 2001). SOST binds to LRP5/ 6 and inhibits the interaction of Wnts with LRP5/6, thus inhibiting Wnt/ $\beta$-catenin signaling (Li et al., 2005b; Ott et al., 2005; Semenov et al., 2005; Semenov and He, 2006). Furthermore, SOST fails to interact with LRP5 carrying the G170V mutation, which is observed in patients with high bone density (Ellies et al., 2006; Semenov and He, 2006).

\section{Secreted frizzled-related proteins}

The secreted frizzled related proteins (sFRPs) are soluble secreted proteins (sFRP1-5) that interact with Wnt and Fz proteins, which prevent the binding of Wnts to the Fz receptors. The sFRPs are structurally related to the Wnt-binding domain of the Fz receptor in that their N-terminal domain, which contains the CRD, shares 30-50\% sequence homology with that of the Fz receptors (Rattner et al., 1997; Kawano and Kypta, 2003). sFRPs antagonize Wnt signaling by interacting with Wnt ligands via the CRD (Lin `et al., 1997). Furthermore, Uren et al. (2000) showed that mutations in the CRD of sFRP1 abrogate its interaction with Drosophila Wg. The same group also showed that the C-terminal domain of sFRP1 interacts with Wnt proteins and that low and high levels of sFRP1 potentiates and inhibits Wg 
signaling, respectively (Uren et al., 2000). sFRP1 can dimerize or interact with the Fz receptor to form a non-functional complex (Bafico et al., 1999), suggesting that the mechanistic actions of sFRP-induced inhibition of Wnt signaling are broad.
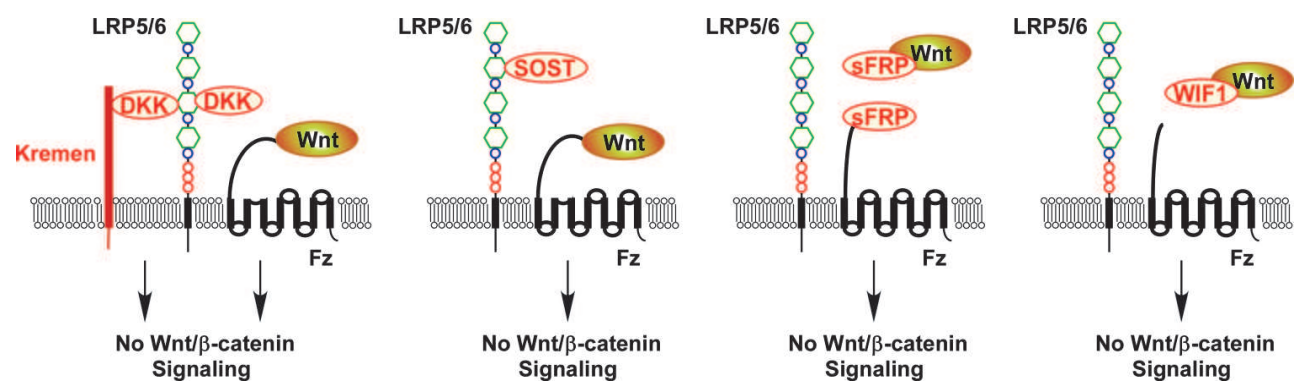

Fig. 3. Secreted Wnt antagonists. By binding to LRP5 or LRP6, Dkk and Sclerostin disrupt Wnt-induced Fz-Wnt-LRP complex and inhibit Wnt/ $\beta$-catenin signaling. Furthermore, Dkk interacts with another transmembrane protein, Kremen. The LRP-Dkk-Kremen complex is internalized, thus removing LRP5/ 6 from the cell surface. WIF1 and sFRPs function as inhibitors of Wnt/ $\beta$-catenin signaling by directly binding to Wnt or both Wnt and Fz.

\section{Wht inhibitory factor-1}

Wnt inhibitory factor-1 (WIF1), another secreted protein that binds to Wnt ligands, is highly conserved in vertebrates, and it was originally discovered as an expressed tag from the human retina (Hsieh et al., 1999). WIF1 consists of an N-terminal signal sequence, a unique WIF domain, and five EGF-like repeats (Hsieh et al., 1999). WIF1 is structurally related to the extracellular domain of RYK (Patthy, 2000; Liepinsh et al., 2006). WIF1 can directly bind Wnt proteins to inhibit Wnt/ $\beta$-catenin signaling (Hsieh et al., 1999). Furthermore, WIF1 can inhibit Wnt-3a-mediated $\beta$-catenin/TCF/LEF transcriptional activity (Surmann-Schmitt et al., 2009) and regulate its own expression through a negative feedback mechanism (Licchesi et al., 2010).

\section{Dysregulation of Wnt signaling in breast cancer}

Although genetic mutations of APC or $\beta$-catenin are rarely observed in certain cancers (e.g. breast cancer), there is compelling evidence that implicates aberrant Wnt/ $\beta$-catenin signaling in breast cancer development. For example, only $6 \%$ of breast tumors contain mutations in the APC gene (Jonsson et al., 2000), which is mutated or deleted in $80 \%$ of colon tumors (Kinzler and Vogelstein, 1996). No mutations occur in the amino terminal of $\beta$ catenin, which contains the CK1 and GSK3 $\beta$ phosphorylation sites (Jonsson et al., 2000). However, elevated $\beta$-catenin expression in breast cancer tissue correlates with a decreased survival rate of breast cancer patients (Jonsson et al., 2000; Dolled-Filhart et al., 2006; LopezKnowles et al., 2010; Zardawi et al., 2009; Khramtsov et al., 2010). Cyclin D1 levels are also elevated in 50\% of patients with breast cancer (Gillet et al., 1994; Bartkova et al., 1994). Indeed, the cyclin D1 promoter region contains a TCF4-binding site, which is regulated by $\beta$-catenin (Tetsu and McCormick, 1999; Shtutman et al., 1999). Elevated $\beta$-catenin expression 
(not due to CTNNB1 activating mutations) and activation is also associated with triplenegative breast cancer and poor clinical prognosis (Geyer et al., 2011). Since elevated expression of $\beta$-catenin and subsequent aberrant activation of $\mathrm{Wnt} / \beta$-catenin signaling in breast cancer development is not due to genetic mutations in APC and $\beta$-catenin, dysregulation of this pathway likely occurs at the cell surface or at the level of epigenetic regulation.

\subsection{Wnt agonists in mammary gland development and breast cancer}

There is compelling evidence that Wnt ligands are involved in the activation of the canonical Wnt signaling pathway during breast cancer development. Wnt1 and Wnt2, the founding members of the Wnt gene family (Nusse and Varmus, 1982; Peters et al., 1983), are tumorigenic. Furthermore, fusion of the Wnt1 allele with the MMTV long terminal repeat and subsequent generation of MMTV-Wnt1 transgenic mice causes mammary gland hyperplasia and increases adenocarcinomas in mice (Tsukamoto et al., 1988). The transforming capability of Wnt genes in mammary epithelial cells is also increased following the insertion of the MMTV (Blasband et al., 1992; Wong et al., 1994). Additionally, the upregulation and transforming capability of several Wnt genes occur in human primary tumors (Dale et al., 1996; Lejeune et al., 1995; Bui et al., 1997). Recently, Oloumi et al. (2010) reported that the rate of mammary tumor growth is significantly increased in Wnt1 and integrin-linked kinase double transgenic mice. Moreover, crosstalk between the Wnt1 and integrin-liked kinase pathways upregulate FOXA1 and estrogen receptor transcription factors, which accelerate breast cancer development (Oloumi et al., 2010). These results implicate Wnt1 in breast cancer development and suggest that Wnt1 may serve as a potential therapeutic target to combat certain forms of breast cancer. Indeed, RNA inhibition of Wnt1 mRNA expression or inhibition of Wnt1 with an antiWnt1 antibody induces apoptosis in a variety of cancer cell lines (e.g. breast cancer) that overexpress Wnt1 (He et al., 2004). Other Wnt proteins, including Wnt10b and Wnt11, are also implicated in breast cancer tumorigenesis. A previous study showed that Wnt $10 \mathrm{~b}$ overexpression induced by the MMTV promoter facilitates mammary gland development and tumor formation in male and female mice (Lane and Leder, 1997). A recent study also showed that the estrogen-related receptor- $\alpha$ and $\beta$-catenin synergistically induce the expression of Wnt11, which facilitates breast cancer migration (Dwyer et al., 2010). This study is compelling because it suggests that combinational therapy could utilize synthetic drugs to target the estrogen-related receptor- $\alpha / \beta$-catenin complex and antibodies to target Wnt11 in order to treat estrogen-dependent breast cancer.

Increasing evidence suggests that non-canonical Wnt signaling also plays a role in mammary gland and breast cancer development. Roarty and Serra (2007) showed that Wnt$5 \mathrm{a}$ is necessary for normal ductal extension and branching. According to previous studies, Wnt-5a activates the Wnt/ $\mathrm{Ca}^{2+}$ signaling pathway, which antagonizes canonical Wnt signaling by inhibiting the downstream transcriptional activity of $\beta$-catenin (Ishitani et al., 2003; Topol et al., 2003; Nemeth et al., 2007). However, a previous study also showed that Wnt-5a can inhibit or activate $\beta$-catenin transcriptional activity (Mikels and Nusse, 2006). This dichotomy is likely due to the availability of cell surface receptors in different cell types. Although controversial, most studies suggest that Wnt-5a likely acts as a tumor suppressor. In one study, Wnt-5a mRNA levels are upregulated 10- and 4-fold in benign and invasive tumors, respectively, compared to that in normal breast tissue (Lejeune et al., 1995). 
It is possible that Wnt-5a may facilitate breast cancer tumorigenesis in a subset of breast cancers given that Wnt-5a can also activate canonical Wnt signaling and that its mRNA levels are increased in some breast tumors. However, several studies have shown that Wnt$5 a$ levels are low in breast cancer tumors and that low Wnt-5a expression may serve as a prognostic indicator of shorter survival rates in some breast cancer patients (Jonsson et al., 2002; Dejmek et al., 2005; Leris et al., 2005). Furthermore, loss of Wnt-5a in normal mouse mammary glands increases canonical Wnt signaling and stimulates mammary tumorigenesis (Roarty et al., 2009). These results suggest that Wnt-5a is generally antitumorigenic and can be supported by previous studies, which showed that Wnt-5a enhances $\beta$-catenin/E-cadherin complex formation via a $\mathrm{Ca}^{2+}{ }^{2+}$ dependent mechanism in human breast epithelial cells (Medrek et al., 2009) and that low Wnt-5a expression enhances migration of ductal breast epithelial cells (Jonsson and Andersson, 2001).

Although there is no direct evidence that implicates Norrin in breast cancer tumorigenesis, there is some evidence that suggests that some members of the R-spondin family of proteins may be involved in the pathogenesis of breast cancer and other forms of cancer. For example, MMTV increases R-spo2 expression in mouse mammary tumors following its insertion into the Int7 locus (Lowther et al., 2005), therefore, implicating hRspo2 in mammary tumorigenesis.

\subsection{Wnt receptors in mammary gland development and breast cancer}

The Wnt co-receptor, LRP5, plays an important role in mammary gland development and in breast cancer. Loss of LRP5 delays mammary gland development and mouse mammary tumor virus (MMTV)-Wnt1-induced tumor formation in mice (Lindvall et al., 2006). Furthermore, a truncated form of LRP5 (LRP5 $\Delta$ ), which is expressed in breast tumors and breast cancer cell lines, could be implicated in mammary gland tumorigenesis (Bjorklund et al., 2009). LRP6 also plays a pivotal role in mammary gland development and breast cancer. Mammary gland development and MMTV-Wnt1-induced mammary tumorigenesis are delayed in $\mathrm{LRP6}^{+/-}$mice (Lindvall et al., 2009). LRP6 expression is also upregulated in basal-like human breast cancer samples (Lindvall et al., 2009). MMTV constructs are also utilized to assess the role of Wnt receptors in mammary development and breast cancer. In fact, MMTV-LRP6 transgenic mice develop hyperplasia in their mammary glands due to LRP6-mediated Wnt/ $\beta$-catenin signaling (Zhang et al., 2010). LRP6 expression is also upregulated in a variety of human breast cancer cell lines, including the basal-like cell line, MDA-MB-231 (Liu et al., 2010). Transcriptional knockdown of LRP6 mRNA in MDA-MB231 cells significantly decreases Wnt signaling, cell proliferation, and tumor growth in SCID mouse models. Furthermore, in vivo administration of an LRP6 antagonist, Mesd, markedly suppressed growth of MMTV-Wnt1 tumors without causing undesirable side effects (Liu et al., 2010). These results suggest that LRP5 and LRP6 are involved in breast cancer development and that these receptors can serve as therapeutic targets for the treatment of breast cancer.

The other Wnt co-receptor, $\mathrm{Fz}$, is also involved in the development of breast cancer. Previously, Saitoh et al. (2002) showed that Fz10 and Wnt2 mRNAs are synchronously upregulated by $\beta$-estradiol treatment in human breast cancer MCF-7 cells, suggesting that increased Fz10 and Wnt2 expression might stimulate breast cancer production. A subsequent study discovered that Fz1 and Fz2 levels are upregulated in advanced infiltrating ductal breast carcinoma (Milovanovic et al., 2004). Furthermore, Benhaj et al. 
(2006) showed that most of the Fz receptors, except Fz9 and Fz10, are expressed in human mammary epithelial cells and most breast cancer cell lines. A recent study discovered that thiazolidinediones, which possess antitumor effects in breast cancer cells, abrogate Wnt/ $\beta$ catenin signaling by negatively regulating the expression of the Wnt co-receptors, Fz1 and LRP6, in human breast cancer MDA-MB-231 and T47D cells (Wang et al., 2009). Another study showed that the anti-helminthic drug, niclosamide, targets the Fz1 receptor by inducing its internalization through endocytosis, which subsequently inhibits Wnt/ $\beta$ catenin signaling (Chen et al., 2009). Overall, these results suggest that the Fz receptor may also serve as a potential target for breast cancer therapy.

\subsection{Inactivation of Wnt antagonists in breast cancer}

Mounting evidence suggests that the frequent occurrence of epigenetic silencing of tumor suppressor genes augments the development and progression of cancer (Ting et al., 2006). Epigenetic silencing of genes occurs via hypermethylation of $\mathrm{CpG}$ dinucleotides in promoter regions of genes or histone modifications (Veeck and Esteller, 2010). For example, sFRP1 mRNA is absent in invasive breast carcinomas (Suzuki et al., 2008; Ugolini et al., 1999, 2001). This is likely due to the hypermethylation of the promoter region of sFRP1 in breast carcinomas (Lo et al., 2006; Veeck et al., 2006). The promoter regions of sFRP2 and sFRP5 are also hypermethylated at a higher frequency than sFRP1 or Dkk1 in several breast cancer cell lines (Suzuki et al., 2008). Furthermore, transcriptional knockdown of sFRP1 robustly increases Wnt signaling in breast cancer cells (Suzuki et al., 2008). A recent study showed that stable overexpression of sFRP1 in human breast cancer MDA-MB-231 cells blocks canonical Wnt signaling with ensuing decreases in cell proliferation and suppression of tumor growth and metastasis in xenograft mouse models (Matsuda et al., 2009). These results suggest that sFRP1 and sFRP5 expression is essential to suppress tumor growth and metastasis. Indeed, sFRP1 hypermethylation in breast cancer tissue is associated with decreased patient survival (Veeck et al., 2006; Veeck et al., 2008). Promoter hypermethylation of sFRP2 also occurs frequently in breast cancer, but it is not associated with patient clinical outcomes (Veeck et al., 2008). Interestingly, sFRP2 is highly expressed in canine mammary tumors and tumor cell lines (Lee et al., 2003, 2004) and its levels correlate with those of $\beta$-catenin; however, there is no correlation between the levels of sFRP2 or $\beta$-catenin with that of cyclin D1. These results suggest, in part, that sFRP2 may serve as a diagnostic marker for breast cancer in humans and dogs, although the mechanistic action of increased sFRP2 expression in canine mammary tumors remains to be elucidated. Another Wnt antagonist, WIF1, is also reduced in $60 \%$ of breast carcinomas (Wissmann et al., 2003). A subsequent study supports the previous finding showing that WIF1 downregulation via hypermethylation of its promoter occurs frequently in breast cancer (Ai et al., 2006). Overall, these studies suggest that epigenetic silencing of Wnt antagonists may be a cause for aberrant Wnt/ $\beta$-catenin signaling, which ultimately results in the development and progression of breast cancer.

\subsection{Dkk1 in breast cancer osteolytic bone metastasis}

Bone is an active tissue maintained by a balance of cellular activities. The osteoblasts are responsible for bone formation. Osteoblasts synthesize and secrete most proteins of the bone extracellular matrix (ECM) and express proteins that are necessary and sufficient to induce mineralization of the ECM. The osteoclasts are multinucleated cells responsible for bone 
resorption. Importantly, the differentiation of osteoclasts is regulated by osteoblasts (Karsenty et al., 2002). Receptor activator of NF-kappaB ligand (RANKL) and macrophagecolony-stimulating factor (M-CSF), both of which are expressed by osteoblastic cells, promote osteoclast differentiation through interaction with their cognate signaling receptors (RANK and c-fms, respectively) (Lacey et al., 1998; Yasuda et al., 1998). This process is regulated by a variety of factors that are produced by osteoblasts, stromal cells, fibroblasts, and lymphocytes. Critically, the secreted decoy receptor of RANKL, osteoprotegerin (OPG), binds to and inhibits the activity of RANKL. OPG inhibits osteoclast formation both in vitro and in vivo (Simonet et al., 1997). The requirement for RANKL, RANK and OPG in the control of osteoclast formation is well established (Suda et al., 1999).

In recent years, Wnt/ $\beta$-catenin signaling has been shown to play a substantial role in the control of bone development and remodeling (for review, see Krishnan et al., 2006). Analyses of patients with the LRP5/6 gene mutations and LRP5/6 knockout mice revealed that the Wnt coreceptors LRP5 and LRP6 play a pivotal role in bone metabolism (Boyden et al., 2002; Gong et al., 2001; Little et al., 2002; Van Wesenbeeck et al., 2003; Ai et al., 2005; Kato et al., 2002; Fujino et al., 2003; Kelly et al., 2004; van Meurs et al., 2006; Holmen et al., 2004; Kokubu et al., 2004). Loss-of-function mutations of human LRP5 are associated with the recessive disorder osteoporosis-pseudoglioma syndrome, whereas gain-of-function mutations of human LRP5 (e.g., G171V) reduce binding affinity of LRP5 for DKK1 and cause high bone mass (HBM) diseases (Boyden et al., 2002; Gong et al., 2001; Little et al., 2002; Van Wesenbeeck et al., 2003; Ai et al., 2005). Direct roles of Wnt/ $\beta$-catenin signaling in the regulation of bone formation and bone mass are further supported by animal model studies by altered expression of Wnt/ $\beta$-catenin signaling inhibitors (Bodine et al., 2004; Li et al., 2006b; Morvan et al., 2006; Wang et al., 2007a; Yu et al., 2005). Wnt proteins have also been shown to be important for osteoblastogenesis and bone formation (Zhang et al., 2004; Li et al., 2005a; Bennett et al., 2005). Furthermore, modulation of Wnt/ $\beta$-catenin signaling in mesenchymal progenitors and osteoblasts reveals that this pathway controls osteoblast differentiation and is critical for bone homeostasis during postnatal life (Day et al., 2005; Glass et al., 2005; Hill et al., 2005; Holmen et al., 2005; Hu et al., 2005). Using a multipotent mesenchymal cell line, OPG expression was found to be upregulated by Wnt/ $\beta$-catenin signaling in an in vitro screen for Wnt-regulated genes (Jackson et al., 2005). Moreover, cellular and molecular studies demonstrated that OPG is a direct target gene of the $\beta$ catenin-TCF complex in osteoblasts (Glass et al., 2005).

Bone metastasis is a frequent complication of cancer. Several tumors show a particular predilection for metastasis to bone, including breast, prostate, and lung cancer and multiple myeloma (Yoneda et al., 1998; Mundy, 2002; Roodman, 2004; Kozlow and Guise, 2005). In the case of breast cancer, up to $70 \%$ of patients with advanced disease develop osteolytic bone metastases, which are a common cause of morbidity and sometimes mortality (Yoneda, 1998). Tumor cells, osteoblasts, osteoclasts, and bone matrix are the four components of a vicious cycle necessary for the initiation and development of bone metastases. Cancer cells are known to produce a variety of stimulators of bone resorption, such as parathyroid hormone related protein (PTHrP) and transforming growth factor (TGF- $\beta$ ). The secretion of some but not all of these factors by cancer cells regulates RANKL and OPG expression in osteoblasts. RANKL stimulates osteoclastic bone resorption by binding to its receptor RANK on osteoclast precursors, while OPG is the secreted decoy receptor of RANKL, and binds to and inhibits the activity of RANKL (Yoneda et al., 1998; Mundy, 2002; Roodman, 2004; Kozlow and Guise, 2005). 


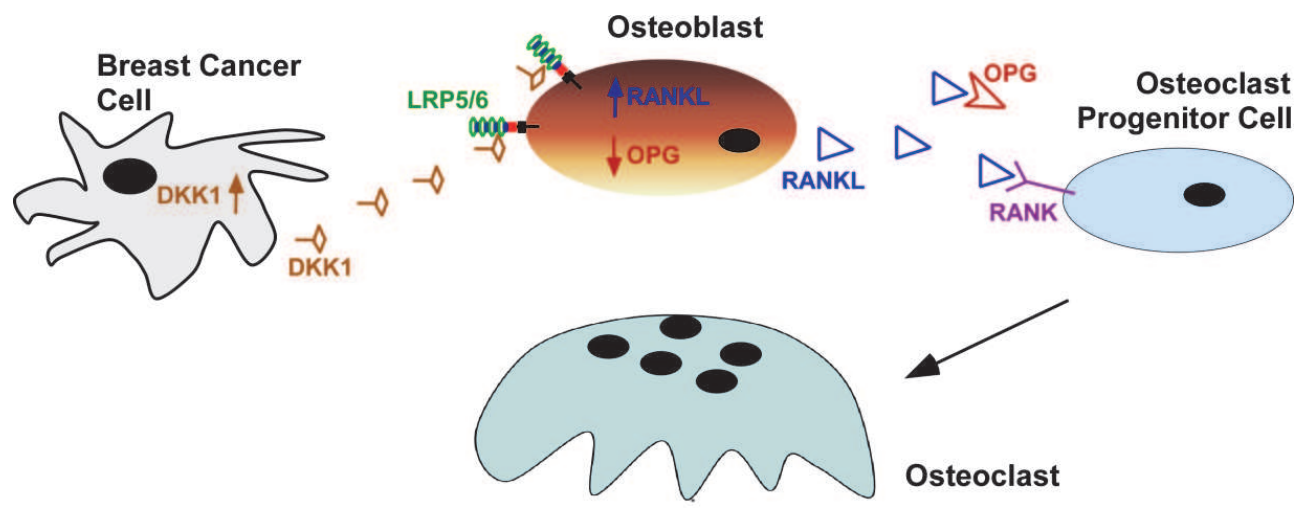

Fig. 4. Model depicting the roles of breast cancer cell-produced DKK1 on osteoclast formation. DKK1 is a Wnt/ $\beta$-catenin signaling target gene in breast cancer cells. Breast cancer cells with overactivated Wnt/ $\beta$-catenin signaling produce DKK1. DKK1 secreted by tumor cells blocks Wnt/ $\beta$-catenin signaling in osteoblasts in a paracrine fashion, resulting in increases RANKL and decreases OPG activity. By decreasing the ratio of OPG to RANKL, DKK1 promotes osteoclastogenesis.

As described above, DKK1 is a specific antagonist of the Wnt/ $\beta$-catenin signaling pathway. Interestingly, studies also suggested that DKK1 is a direct downstream target of Wnt/ $\beta$ catenin signaling (Niida et al., 2004; Gonzalez-Sancho et al., 2005; Chamorro et al., 2005). Activation of $\mathrm{Wnt} / \beta$-catenin signaling by Wnt1 or ectopic expression of active $\beta$-catenin, TCF4 or LRP6 mutants induces transcription of the human Dkk1 gene in several cell line models in vitro. Multiple $\beta$-catenin/TCF4 binding sites in the Dkk1 gene promoter region contribute to this activation (Niida et al., 2004; Gonzalez-Sancho et al., 2005; Chamorro et al., 2005). Furthermore, as mentioned above, aberrant Wnt/ $\beta$-catenin signaling is involved in breast cancer development and progression. Indeed, Dkk1 is highly expressed in several breast cancer cell lines, including the MDA-MB-231 (osteolytic) and MCF-7 (osteolytic and osteoblastic) cell lines (Forget et al., 2007; Pinzone et al., 2009; Bu et al., 2008). Additionally, serum Dkk1 levels were elevated in patients with metastasized breast cancer in the bone compared to patients who were in complete remission (Voorzanger-Rousselot et al., 2007). Dkk1-mediated bone metastasis in breast cancer patients is likely to occur as a result of Dkk1 acting as a molecular switch, which decreases osteoblastogenesis and increases osteolysis (Fig. 4). The mechanistic actions of Dkk1-mediated bone metastasis in breast cancer patients is likely due to the ability of Dkk1 to abrogate Wnt/ $\beta$-catenin signaling in osteoblasts, which causes a significant decrease in OPG and increase in RANKL levels, thus shifting the balance in the OPG:RANKL ratio (Bu et al., 2008). Increases in RANKL promote osteoclastogenesis and thus, metastasis of breast cancer mesenchymal stem cells into the bone (Pinzone et al., 2009).

\subsection{Wnt/ $\beta$-catenin signaling in breast cancer EMT}

Cellular diversity is essential for the development and sustenance of eukaryotic organisms. Epithelial and mesenchymal cells represent two phenotypic distinctions of early organisms. Epithelial cells possess tight junctions, gap junctions, E-cadherins, and epithelial integrins, which foster intercellular communication and fusion with other cells 
and the extracellular matrix. They also maintain the integrity and regulate the internal environment of an organism (Micalizzi et al., 2010). Mesenchymal cells, which produce the extracellular matrix that supports epithelial cells, are motile compared to their epithelial counterpart (Hay, 2005). Mammalian development is a dynamic process that involves the interconversion between epithelial and mesenchymal cells known as Epithelial-Mesenchymal Transition (EMT) and Mesenchymal-Epithelial Transition (MET) (Micalizzi et al., 2010). The EMT plays a pivotal role in wound healing, fibrosis, and cancer metastasis (Lopez-Novoa and Nieto, 2009). The EMT consists of three types, which include development (type I), fibrosis and wound healing (type II), and cancer (type III) (Kalluri and Weinberg, 2009). Oncogenic EMT is characterized by the loss of the classical epithelial apico-basal polarity, destruction of tight junctions and adherens junctions, and the downregulation of cytokeratins followed by the upregulation of vimentin, a Type III intermediate filament that is expressed in mesenchymal cells (Steinert and Roop, 1988; Ikenouchi et al., 2003; Kokkinos et al., 2007).

Normal epithelial cells are transformed into more invasive mesenchymal cells due to the disintegration of E-cadherin. E-cadherin is a transmembrane glycoprotein that mediates cell-cell contact between epithelial cells. The cytoplasmic domain of E-cadherin interacts with $\alpha-, \beta$, and $\gamma$-catenin. Under normal cellular conditions, $\beta$-catenin forms a complex with E-cadherin to maintain epithelial cell adhesion (Gottardi et al., 2001). However, during epithelial transformation, $\beta$-catenin dissociates from the E-cadherin complex and translocates to the nucleus where it synergizes with TCF/LEF1 to induce the expression of downstream target genes (Behrens et al., 1996). The upregulation of $\beta$-catenin transcriptional activity induces the expression of vimentin in breast cancer cells, which is a key mediator in EMT (Gilles et al., 2003). The snail and slug zinc-finger transcription factors, which are E-cadherin repressors, are associated with EMT and upregulation of these proteins in breast cancer correlates with poor prognosis of breast cancer patients (Blanco et al., 2002; Moody et al., 2005; Martin et al., 2005). Indeed, aberrant Wnt/ $\beta$ catenin signaling increases Snail activity (Yook et al., 2006). Other proteins that contribute to the invasive properties of epithelial cells including matrix metalloproteinase-7, CD44, UPAAR, slug, and the $\gamma 2$ chain of laminin- 5 are also downstream target genes of $\beta$-catenin (Brabletz et al., 1999; Wielenga et al., 1999; Mann et al., 1999; Hlubek et al., 2001). Overall, dysfunction of the $\mathrm{Wnt} / \beta$-catenin signaling pathway is intricately involved in regulating the EMT of breast cancer.

\subsection{Wnt/ $\beta$-catenin signaling in breast cancer stem cells}

Stem cells are cells that have the capacity to propagate or differentiate into distinct cell types that form mature tissue (Seaberg and Kooy, 2003). Stem cells may lay dormant and accumulate mutations over a long period of time, which ultimately results in the formation of tumors due to aberrant activation of signaling pathways that regulate stem cell continuity and differentiation (Sell, 2004). Previously, stem cells were isolated from human breast cancer tissue, suggesting that cancer stem cells (CSCs) may be involved in the development of breast cancer (Al-Hajj et al., 2003). Breast CSCs are characterized by the expression of cell surface markers including stem cell antigen-1 (Welm et al., 2002), CD44+/CD24-, aldehyde dehydrogenase-1 (ALDH1), ESA, PROCR, CD133, and CXCR4 (Nguyen et al., 2010). Another indicator of breast CSCs is their ability to efflux Hoechst 33342 dye (Alvi et al., 2003; Hirschmann-Jax et al., 2004; Ho et al., 2007). ALDH is a detoxifying enzyme, which oxidizes intracellular aldehydes (Duester, 2000; Magni et al., 1996; Sophos and Vasiliou, 
2003; Yoshida et al., 1998). CD44+/CD24- breast CSCs, which express pro-invasive genes, usually display poor prognosis (Sheridan et al., 2006). A recent study showed that metastatic breast cancer in xenograft mouse models display high ALDH1 activity, which may serve as a predictor of poor patient survival (Charafe-Jauffret et al., 2010). Furthermore, breast CSCs positive for ALDH1 but not CD44+/CD24- are resistant to chemotherapy (Tanei et al., 2009), suggesting that ALDH1 expression may be essential for breast CSC propagation and contribute to drug resistance in some breast cancer types. Indeed, ALDH1-positive tumors are more likely to be ER-, PR-, and HER2+ and exhibit poor prognosis (Morimoto et al., 2009). However, the involvement of ALDH1 in breast CSC development is still controversial. One study showed that there is no correlation between ALDH1 expression and ER and PR status and poor patient survival (Restkova et al., 2010). Furthermore, Restkova et al. (2010) showed that ALDH1 is highly expressed in the stroma of breast cancer tumors and is associated with increased survival.

The Wnt/ $\beta$-catenin signaling pathway plays an important role in stem cell survival by maintaining their continuity and undifferentiated state (Ling et al., 2009). Aberrant Wnt/ $\beta$ catenin signaling, which may be induced by mutations in the stem cell genome, contributes to the development and progression of breast CSCs. For example, previous studies show that $\beta$-catenin positively regulates the expression of CD44 and CD24 (Wielenga et al., 1999, 2000; Shulewitz et al., 2006). Furthermore, increased cytoplasmic and nuclear localization of $\beta$-catenin in basal-like breast cancer overlaps with CD44+/CD24- staining, which suggest that CSC populations exist in basal-like/triple negative breast tumors (Khramtsov et al., 2010). The canonical Wnt signaling co-receptor, LRP6 is overexpressed in triple-negative breast cancer (Liu et al., 2010) and facilitates the metastasis of triple-negative breast tumors (DiMeo et al., 2009). Expression of Wnt1 and stabilized $\beta$-catenin ( $\Delta$ N89 $\beta$-catenin) under the MMTV promoter induces Wnt/ $\beta$-catenin signaling in distinct progenitor compartments in mouse mammary tumors (Teissedre et al. 2009). Wnt/ $\beta$-catenin signaling also mediates the radiation resistance of mouse mammary progenitor cells (Chen et al., 2007; Woodward et al., 2007). These results suggest that aberrant Wnt/ $\beta$-catenin converts normal mammary stem cells into CSCs by altering their self-renewal and differentiation capabilities.

\section{Conclusion}

Aberrant activation of the Wnt/ $\beta$-catenin signaling pathway can lead to tumor formation. While genetic mutations of certain intracellular components of the Wnt/ $\beta$-catenin pathway, such as APC and CTNNB1, are significant contributing factors for colorectal cancers, they are typically not the predominate mechanism associated with breast cancer. Instead, it is clear that dysregulation of cell surface Wnt/ $\beta$-catenin signaling components leads to aberrant activation of this pathway in breast cancer. Studies in the past years have demonstrated that Wnt/ $\beta$-catenin signaling play a critical role in breast development and progression. Therefore, disruption of Wnt/ $\beta$-catenin signaling at the cell surface represents a great opportunity to develop novel drugs for breast cancer prevention and therapy (Ettenberg et al., 2010; Gong et al., 2010; Liu et al., 2010).

\section{Acknowledgment}

Research in authors' laboratory is supported by a grant from the National Institutes of Health (R01CA124531). 


\section{References}

Ai L, Tao Q, Zhong S, Fields CR, Kim WJ, Lee MW, Cui Y, Brown KD, and Robertson KD. 2006. Inactivation of Wnt inhibitory factor-1 (WIF1) expression by epigeneticsilencing is a common event in breast cancer. Carcinogenesis. 27 (7): 13411348.

Ai M, Holmen SL, van Hul W, Williams BO, and Warman ML. 2005. Reduced affinity to and inhibition by DKK1 form a common mechanism by which high bone massassociated missense mutations in LRP5 affect canonical Wnt signaling. Mol Cell Biol 25 (12): 4946-4955.

Al-Hajj M, Wicha MS, Benito-Hernandez A, Morrison SJ, and Clarke MF. 2003. Prospectiveidentification of tumorigenic breast cancer cells. Proc Natl Acad Sci U S A. 100 (7): 3983-3988.

Alvi AJ, Clayton H, Joshi C, Enver T, Ashworth A, Vivanco MM, Dale TC, and SmalleyMJ. 2002. Functional and molecular characterisation of mammary side population cells. Breast Cancer Res 5 (1): R1-R8.

Arteaga CL. 2003. Trastuzumab, an appropriate first-line single-agent therapy for HER2overexpressing metastatic breast cancer. Breast Cancer Res 5 (2): 96-100.

Bafico A, Gazit A, Pramila T, Finch PW, Yaniv A, and Aaronson SA. 1999. Interaction of frizzled related protein (FRP) with Wnt ligands and the frizzled receptor suggests alternative mechanisms for FRP inhibition of Wnt signaling. J Biol Chem 274 (23): 16180-16187.

Bafico A, Liu G, Yaniv A, Gazit A, and Aaronson SA. 2001. Novel mechanism of Wntsignalling inhibition mediated by Dickkopf-1 interaction with LRP6/Arrow. Nat Cell Biol. 3 (7): 683-686.

Balemans W, Ebeling M, Patel N, Van Hul E, Olson P, Dioszegi M, Lacza C, WuytsW, Van Den Ende J, Willems P, Paes-Alves AF, Hill S, Bueno M, Ramos FJ, TacconiP, Dikkers FG, Stratakis C, Lindpaintner K, Vickery B, Foernzler D, and Van Hul W. 2001. Increased bone density in sclerosteosis is due to the deficiency of a novel secreted protein (SOST). Hum Mol Genet 10 (5): 537-543.

Bänziger C, Soldini D, Schütt C, Zipperlen P, Hausmann G, and Basler K. 2006. Wntless, a conserved membrane protein dedicated to the secretion of Wnt proteins from signaling cells. Cell 125 (3): 509-522.

Bartkova J, Lukas J, Müller H, Lützhøft D, Strauss M, and Bartek J. 1994. Cyclin D1 protein expression and function in human breast cancer. Int J Cancer 57 (3): 353-361.

Bartscherer K, Pelte N, Ingelfinger D, and Boutros M. 2006. Secretion of Wnt ligands requires Evi, a conserved transmembrane protein. Cell 125 (3): 523-533.

Behrens J, von Kries JP, Kühl M, Bruhn L, Wedlich D, Grosschedl R, and Birchmeier W. 1996. Functional interaction of beta-catenin with the transcription factor LEF-1. Nature 382 (6592): 638-642.

Bennett CN, Longo KA, Wright WS, Suva LJ, Lane TF, Hankenson KD, and MacDougald OA. 2005. Regulation of osteoblastogenesis and bone mass by Wnt10b. Proc Natl Acad Sci U S A 102 (9): 3324-3329.

Benhaj K, Akcali KC, and Ozturk M. 2006. Redundant expression of canonical Wnt ligands in human breast cancer cell lines. Oncol Rep 15 (3): 701-707. 
Berger W, Meindl A, van de Pol TJ, Cremers FP, Ropers HH, Döerner C, Monaco A, Bergen AA, Lebo R, Warburgh $\mathrm{M}$, et al. 1992. Isolation of a candidate gene for Norriedisease by positional cloning. Nat Genet 2(1): 84 .

Björklund P, Svedlund J, Olsson AK, Akerström G, and Westin G. 2009. The internally truncated LRP5 receptor presents a therapeutic target in breast cancer. PLoS One 4(1): e4243.

Blanco MJ, Moreno-Bueno G, Sarrio D, Locascio A, Cano A, Palacios J, and Nieto MA. 2002. Correlation of Snail expression with histological grade and lymph node status in breast carcinomas. Oncogene 21(20): 3241-3246.

Blasband A, Schryver B, and Papkoff J. 1992. The biochemical properties and transforming potential of human Wnt-2 are similar to Wnt-1. Oncogene 7 (1): 153-161.

Bodine PV, Zhao W, Kharode YP, Bex FJ, Lambert AJ, Goad MB, Gaur T, Stein GS, Lian JB, and Komm BS. 2004. The Wnt antagonist secreted frizzled-related protein-1 is a negative regulator of trabecular bone formation in adult mice. Mole Endocrinol 18 (5): 1222-1237.

Bourhis E, Tam C, Franke Y, Bazan JF, Ernst J, Hwang J, Costa M, Cochran AG, and Hannoush RN. 2010. Reconstitution of a frizzled8.Wnt3a. LRP6 signaling complex reveals multiple Wnt and Dkk1 binding sites on LRP6. J Biol Chem 285 (12): 91729179.

Boyden LM, Mao J, Belsky J, Mitzner L, Farhi A, Mitnick MA, Wu D, Insogna K, and Lifton RP. 2002. High bone density due to a mutation in LDL-receptor-related protein $5 . \mathrm{N}$ Engl J Med 346 (20): 1513-1521.

Brabletz T, Jung A, Dag S, Hlubek F, and Kirchner T. 1999. $\beta$-Catenin regulates the expression of the matrix metalloproteinase-7 in human colorectal cancer. Am J Pathol 155(4): 1033-1038.

Brennan K, Gonzalez-Sancho JM, Castelo-Soccio LA, Howe LR, and Brown AM. 2004. Truncated mutants of the putative Wnt receptor LRP6/Arrow can stabilize betacatenin independently of Frizzled proteins. Oncogene 23: 4873-4884.

Brott BK and Sokol SY. 2002. Regulation of Wnt/LRP signaling by distinct domains of Dickkopf proteins. Mol Cell Biol 22 (17): 6100-6110.

Brunkow ME, Gardner JC, Van Ness J, Paeper BW, Kovacevich BR, Proll S, Skonier JE, Zhao L, Sabo PJ, Fu Y, Alisch RS, Gillett L, Colbert T, Tacconi P, Galas D,Hamersma H, Beighton P, and Mulligan J. 2001. Bone dysplasia sclerosteosis results from loss of the SOST gene product, a novel cystine knot-containing protein. Am J Hum Genet 68(3): 577-589.

Bu G, Lu W, Liu CC, Selander K, Yoneda T, Hall C, Keller ET, and Li Y. 2008. Breast cancerderived Dickkopf1 inhibits osteoblast differentiation and osteoprotegerin expression: implication for breast cancer osteolytic bone metastases. Int J Cancer 123 (5): 1034-1042.

$\mathrm{Bu}$ G. 2009. Apolipoprotein E and its receptors in Alzheimer's disease: pathways, pathogenesis and therapy. Nat Rev Neurosci 10 (5): 333-344.

Bui TD, Rankin J, Smith K, Huguet EL, Ruben S, Strachan T, Harris AL, and Lindsay S. 1997. A novel human Wnt gene, WNT10B, maps to $12 \mathrm{q} 13$ and is expressed in human breastcarcinomas. Oncogene 14(10): 1249-1253.

Cabrera CV, Alonso MC, Johnston P, Phillips RG, and Lawrence PA. 1987. Phenocopies induced with antisense RNA identify the wingless gene. Cell 50 (4): 659-663. 
Chamorro MN, Schwartz DR, Vonica A, Brivanlou AH, Cho KR, and Varmus HE. 2005. FGF-20 and DKK1 are transcriptional targets of beta-catenin and FGF-20 is implicated in cancer and development. EMBO J 24 (1): 73-84.

Caricasole A, Ferraro T, Iacovelli L, Barletta E, Caruso A, Melchiorri D, Terstappen GC, and Nicoletti F. 2003. Functional characterization of WNT7A signaling in PC12 cells: interaction with A FZD5 x LRP6 receptor complex and modulation by Dickkopf proteins. J Biol Chem 278 (39): 37024-37031.

Carter P, Presta L, Gorman CM, Ridgway JB, Henner D, Wong WL, Rowland AM, Kotts C, Carver ME, and Shepard HM. 1992. Humanization of an anti-p185HER2 antibody for human cancer therapy. Proc Natl Acad Sci U S A 89 (10): 4285-4289.

Charafe-Jauffret E, Ginestier C, Iovino F, Tarpin C, Diebel M, Esterni B, Houvenaeghel G, Extra JM, Bertucci F, Jacquemier J, Xerri L, Dontu G, Stassi G,Xiao Y, Barsky SH, Birnbaum D, Viens P, and Wicha MS. 2010. Aldehyde dehydrogenase 1-positive cancer stem cells mediate metastasis and poor clinical outcome ininflammatory breast cancer. Clin Cancer Res 16 (1): 45-55.

Chen ZY, Hendriks RW, Jobling MA, Powell JF, Breakefield XO, Sims KB, and Craig IW. 1992. Isolation and characterization of a candidate gene for Norrie disease. Nat Genet 1 (3): 204-208.

Chen MS, Woodward WA, Behbod F, Peddibhotla S, Alfaro MP, Buchholz TA, and Rosen JM. 2007. Wnt/beta-catenin mediates radiation resistance of Sca1+ progenitors in animmortalized mammary gland cell line. J Cell Sci 120 (3): 468-477.

Chen M, Wang J, Lu J, Bond MC, Ren XR, Lyerly HK, Barak LS, and Chen W. 2009. The antihelminthic niclosamide inhibits Wnt/Frizzled1 signaling. Biochemistry 48(43): 10267-10274.

Culi J and Mann RS. 2003. Boca, an endoplasmic reticulum protein required for wingless signaling and trafficking of LDL receptor family members in Drosophila. Cell 112 (3): 343-354.

Culi J, Springer TA, and Mann RS. 2004. Boca-dependent maturation of beta-propeller/EGF modules in low-density lipoprotein receptor proteins. EMBO J 23 (6): 1372-1380.

Dale TC, Weber-Hall SJ, Smith K, Huguet EL, Jayatilake H, Gusterson BA, Shuttleworth G, O'Hare M, and Harris AL. 1996. Compartment switching of WNT-2 expression inhuman breast tumors. Cancer Res 56 (19): 4320-4323.

Davidson G, Mao B, del Barco Barrantes I, and Niehrs C. 2002. Kremen proteins interact with Dickkopf1 to regulate anteroposterior CNS patterning. Development 129 (24): 5587-5596.

Davidson G, Wu W, Shen J, Bilic J, Fenger U, Stannek P, Glinka A, and Niehrs C. 2005. Casein kinase 1 gamma couples Wnt receptor activation to cytoplasmic signal transduction. Nature 438 (7069): 867-872.

Day TF, Guo X, Garrett-Beal L, and Yang Y. 2005. Wnt/beta-catenin signaling in mesenchymal progenitors controls osteoblast and chondrocyte differentiation during vertebrate skeletogenesis. Dev Cell 8 (5): 739-750.

Dejmek J, Leandersson K, Manjer J, Bjartell A, Emdin SO, Vogel WF, Landberg G, and Andersson T. 2005. Expression and signaling activity of Wnt-5a/discoidin domainreceptor-1 and Syk plays distinct but decisive roles in breast cancer patient survival. Clin Cancer Res. 11 (2 Pt 1): 520-528. 
Diehn M, Cho RW, Lobo NA, Kalisky T, Dorie MJ, Kulp AN, Qian D, Lam JS, AillesLE, Wong M, Joshua B, Kaplan MJ, Wapnir I, Dirbas FM, Somlo G, Garberoglio C, Paz B, Shen J, Lau SK, Quake SR, Brown JM, Weissman IL, Clarke MF. 2009. Association of reactive oxygen species levels and radioresistance in cancer stem cells. Nature 458 (7239): 780-783.

DiMeo TA, Anderson K, Phadke P, Fan C, Perou CM, Naber S, and Kuperwasser C. 2009. A novel lung metastasis signature links Wnt signaling with cancer cell selfrenewaland epithelial-mesenchymal transition in basal-like breast cancer. Cancer Res 69 (3): 5364-5373.

Dolled-Filhart M, McCabe A, Giltnane J, Cregger M, Camp RL, and Rimm DL. 2006. Quantitative in situ analysis of beta-catenin expression in breast cancer shows decreased expression is associated with poor outcome. Cancer Res 66 (10); 54875494.

Duester G. 2000. Families of retinoid dehydrogenases regulating vitamin A function: production of visual pigment and retinoic acid. Eur J Biochem 267(14): 4315-4324.

Dwyer MA, Joseph JD, Wade HE, Eaton ML, Kunder RS, Kazmin D, Chang CY, and McDonnell DP. 2010. WNT11 expression is induced by estrogen-related receptor alpha and beta-catenin and acts in an autocrine manner to increase cancer cell migration. Cancer Res 70(22): 9298-9308.

Ellies DL, Viviano B, McCarthy J, Rey JP, Itasaki N, Saunders S, and Krumlauf R. 2006. Bone density ligand, Sclerostin, directly interacts with LRP5 but not LRP5G171Vto modulate Wnt activity. J Bone Miner Res 21 (11): 1738-1749.

Ettenberg SA, Charlat O, Daley MP, Liu S, Vincent KJ, Stuart DD, Schuller AG, Yuan J, Ospina B, Green J, Yu Q, Walsh R, Li S, Schmitz R, Heine H, Bilic S, Ostrom L, Mosher R, Hartlepp KF, Zhu Z, Fawell S, Yao YM, Stover D, Finan PM, Porter JA, Sellers WR, Klagge IM, and Cong F. 2010. Inhibition of tumorigenesis driven bydifferent Wnt proteins requires blockade of distinct ligand-binding regions byLRP6 antibodies. Proc Natl Acad Sci U S A 107(35): 15473-15478.

Forget MA, Turcotte S, Beauseigle D, Godin-Ethier J, Pelletier S, Martin J, Tanguay S, and Lapointe R. 2007. The Wnt pathway regulator DKK1 is preferentially expressedin hormone-resistant breast tumours and in some common cancer types. $\mathrm{Br} J$ Cancer 96 (4): 646-653.

Fujino T, Asaba H, Kang MJ et al. 2003. Low-density lipoprotein receptor-related protein 5 (LRP5) is essential for normal cholesterol metabolism and glucose-induced insulin secretion. Proc Natl Acad Sci U S A. 100: 229-234.

Geyer FC, Lacroix-Triki M, Savage K, Arnedos M, Lambros MB, MacKay A, Natrajan R, and Reis-Filho JS. 2011. $\beta$-Catenin pathway activation in breast cancer is associatedwith triple-negative phenotype but not with CTNNB1 mutation. Mod Pathol 24 (2): 209231.

Gilles C, Polette M, Mestdagt M, Nawrocki-Raby B, Ruggeri P, Birembaut P, and Foidart JM. 2003. Transactivation of vimentin by beta-catenin in human breast cancercells. Cancer Res 63 (10): 26658-26664.

Gillett C, Fantl V, Smith R, Fisher C, Bartek J, Dickson C, Barnes D, and Peters G. 1994. Amplification and overexpression of cyclin D1 in breast cancer detected byimmunohistochemical staining. Cancer Res 54 (7): 1812-1817. 
Glass DA 2nd, Bialek P, Ahn JD, Starbuck M, Patel MS, Clevers H, Taketo MM, Long F, McMahon AP, Lang RA, and Karsenty G. 2005. Canonical Wnt signaling in differentiated osteoblasts controls osteoclast differentiation. Dev Cell 8 (5): 751-764.

Glinka A, Wu W, Delius H, Monaghan AP, Blumenstock C, and Niehrs C. 1998. Dickkopf-1 is a member of a new family of secreted proteins and functions in head induction. Nature 391(6665): 357-362.

Gong Y, Slee RB, Fukai N, Rawadi G, Roman-Roman S, Reginato AM, Wang H, Cundy T, Glorieux FH, Lev D, Zacharin M, Oexle K, Marcelino J, Suwairi W, Heeger S, Sabatakos G, Apte S, Adkins WN, Allgrove J, Arslan-Kirchner M, Batch JA, Beighton P, Black GC, Boles RG, Boon LM, Borrone C, Brunner HG, Carle GF, Dallapiccola B, De Paepe A, Floege B, Halfhide ML, Hall B, Hennekam RC, Hirose T, Jans A, Jüppner H, Kim CA, Keppler-Noreuil K, Kohlschuetter A, LaCombe D, Lambert M, Lemyre E, Letteboer T, Peltonen L, Ramesar RS, Romanengo M, Somer H, Steichen-Gersdorf E, Steinmann B, Sullivan B, Superti-Furga A, Swoboda W, van den Boogaard MJ, Van Hul W, Vikkula M, Votruba M, Zabel B, Garcia T, Baron R, Olsen BR, Warman ML; and Osteoporosis-Pseudoglioma Syndrome Collaborative Group. 2001. LDL receptor-related protein 5 (LRP5) affects bone accrual and eye development. Cell 107 (4): 513-523.

Gong Y, Bourhis E, Chiu C, Stawicki S, DeAlmeida VI, Liu BY, Phamluong K, Cao TC, Carano RA, Ernst JA, Solloway M, Rubinfeld B, Hannoush RN, Wu Y, Polakis P, and Costa M. 2010. Wnt isoform-specific interactions with coreceptor specify inhibition or potentiation of signaling by LRP6 antibodies. PLoS One 5 (9): e12682.

González-Sancho JM, Aguilera O, García JM, Pendás-Franco N, Peña C, Cal S, García de Herreros A, Bonilla F, and Muñoz A. 2005. The Wnt antagonist DICKKOPF-1 gene is a downstream target of beta-catenin/TCF and is downregulated in human colon cancer. Oncogene 24 (6): 1098-1103.

Gottardi CJ and Gumbiner BM. 2001. Adhesion signaling: how beta-catenin interacts with its partners. Curr Biol 11 (19): R792-R794.

Hay ED. 2005. The mesenchymal cell, its role in the embryo, and the remarkablesignaling mechanisms that create it. Dev Dyn 233 (3): 706-720.

He B, You L, Uematsu K, Xu Z, Lee AY, Matsangou M, McCormick F, and Jablons DM. 2004. A monoclonal antibody against Wnt-1 induces apoptosis in human cancer cells. Neoplasia 6 (1): 7-14.

He X, Semenov M, Tamai K, and Zeng X. 2004. LDL receptor-related proteins 5 and 6 in Wnt/beta-catenin signaling: arrows point the way. Development 131 (8): 1663-1677.

Hendrickx M and Leyns L. 2008. Non-conventional Frizzled ligands and Wnt receptors. Dev Growth Differ 50 (4): 229-243.

Hey PJ, Twells RC, Phillips MS, Yusuke Nakagawa, Brown SD, Kawaguchi Y, Cox R, Guochun Xie, Dugan V, Hammond H, Metzker ML, Todd JA, and Hess JF. 1998. Cloning of a novel member of the low-density lipoprotein receptor family. Gene 216 (1): 103-111.

Hill TP, Spater D, Taketo MM, Birchmeier W, and Hartmann C. 2005. Canonical Wnt/betacatenin signaling prevents osteoblasts from differentiating into chondrocytes. Dev Cell 8 (5): 727-738. 
Hirschmann-Jax C, Foster AE, Wulf GG, Nuchtern JG, Jax TW, Gobel U, Goodell MA, and Brenner MK. 2004. A distinct "side population" of cells with high drug effluxcapacity in human tumor cells. Proc Natl Acad Sci U S A 101 (39): 14228-14233.

Hlubek F, Jung A, Kotzor N, Kirchner T, and Brabletz T. 2001. Expression of the invasion factor laminin gamma2 in colorectal carcinomas is regulated by beta-catenin.Cancer Res 61 (22): 8089-8093.

Ho MM, Ng AV, Lam S, and Hung JY. 2007. Side population in human lung cancer cell lines and tumors is enriched with stem-like cancer cells. Cancer Res 67 (10): 4827-4833.

Holmen SL, Giambernardi TA, Zylstra CR, Buckner-Berghuis BD, Resau JH, Hess JF, Glatt V, Bouxsein ML, Ai M, Warman ML, and Williams BO. 2004. Decreased BMD and limb deformities in mice carrying mutations in both Lrp5 and Lrp6. J Bone Miner Res 19 (12): 2033-2040.

Holmen SL, Zylstra CR, Mukherjee A, Sigler RE, Faugere MC, Bouxsein ML, Deng L, Clemens TL, and Williams BO. 2005. Essential role of beta-catenin in postnatal bone acquisition. J Biol Chem 280: 21162-21168.

Hsieh JC, Kodjabachian L, Rebbert ML, Rattner A, Smallwood PM, Samos CH, Nusse R, Dawid IB, and Nathans J. 1999. A new secreted protein that binds to Wnt proteins andinhibits their activities. Nature 398 (6726): 431-436.

Hsieh JC, Lee L, Zhang L, Wefer S, Brown K, DeRossi C, Wines ME, Rosenquist T, and Holdener BC. 2003. Mesd encodes an LRP5/ 6 chaperone essential for specification of mouse embryonic polarity. Cell 112 (3): 355-367.

$\mathrm{Hu}$ H, Hilton MJ, Tu X, Yu K, Ornitz DM, and Long F. 2005. Sequential roles of Hedgehog and Wnt signaling in osteoblast development. Development 132 (1): 49-60.

Ikenouchi J, Matsuda M, Furuse M, and Tsukita S. 2003. Regulation of tight junctions during the epithelium-mesenchyme transition: direct repression of the geneexpression of claudins/occludin by Snail. J Cell Sci 116 (Pt 10): 1959-1967.

Ishitani T, Kishida S, Hyodo-Miura J, Ueno N, Yasuda J, Waterman M, Shibuya H, Moon RT, Ninomiya-Tsuji J, and Matsumoto K. 2003. The TAK1-NLK mitogen-activated proteinkinase cascade functions in the $\mathrm{Wnt}-5 \mathrm{a} / \mathrm{Ca}(2+)$ pathway to antagonize Wnt/beta-catenin signaling. Mol Cell Biol 23 (1): 131-139.

Jackson A, Vayssiere B, Garcia T, Newell W, Baron R, Roman-Roman S, and Rawadi G. 2005. Gene array analysis of Wnt-regulated genes in C3H10T1/2 cells. Bone 36 (4): $585-$ 598.

Jönsson M, Borg A, Nilbert M, and Andersson T. 2000. Involvement of adenomatous polyposis coli (APC)/beta-catenin signalling in human breast cancer. Eur J Cancer. 36 (2): 242-248.

Jönsson M and Andersson T. 2001. Repression of Wnt-5a impairs DDR1 phosphorylation and modifies adhesion and migration of mammary cells. J Cell Sci 114 (Pt 11): 20432053.

Jönsson M, Dejmek J, Bendahl PO, and Andersson T. 2002. Loss of Wnt-5a protein is associated with early relapse in invasive ductal breast carcinomas. Cancer Res 62 (2): 409-416.

Kalluri R, and Weinberg RA. 2009. The basics of epithelial-mesenchymal transition. J Clin Invest 119 (6): 1420-1428. 
Kazanskaya O, Glinka A, del Barco Barrantes I, Stannek P, Niehrs C, and Wu W. 2004. RSpondin2 is a secreted activator of Wnt/beta-catenin signaling and is required for Xenopus myogenesis. Dev Cell 7 (4): 525-534.

Karsenty G, and Wagner EF. 2002. Reaching a genetic and molecular understanding of skeletal development. Dev Cell 2 (4): 389-406.

Kato M, Patel MS, Levasseur R, Lobov I, Chang BH, Glass DA 2nd, Hartmann C, Li L, Hwang TH, Brayton CF, Lang RA, Karsenty G, and Chan L. 2002. Cbfa1independent decrease in osteoblast proliferation, osteopenia, and persistent embryonic eye vascularization in mice deficient in LRP5, a Wnt coreceptor. J. Cell Biol 157 (2): 303-314.

Kawano Y and Kypta R. 2003. Secreted antagonists of the Wnt signalling pathway. J Cell Sci 116 (13): 2627-2634.

Kelly OG, Pinson KI, and Skarnes WC. 2004. The Wnt co-receptors LRP5 and LRP6 are essential for gastrulation in mice. Development 131 (12): 2803-2815.

Khramtsov AI, Khramtsova GF, Tretiakova M, Huo D, Olopade OI, and Goss KH. 2010. Wnt/beta-catenin pathway activation is enriched in basal-like breast cancers and predicts poor outcome. Am J Pathol 176 (6): 2911-2920.

Kim KA, Kakitani M, Zhao J, Oshima T, Tang T, Binnerts M, Liu Y, Boyle B, Park E, Emtage P, Funk WD, Tomizuka K. 2005. Mitogenic influence of human R-spondin1 on the intestinal epithelium. Science 309(5738): 1256-1259.

Kim KA, Zhao J, Andarmani S, Kakitani M, Oshima T, Binnerts ME, Abo A, Tomizuka K, and Funk WD. 2006. R-Spondin proteins: a novel link to beta-catenin activation. Cell Cycle 5 (1): 23-26.

Kim KA, Wagle M, Tran K, Zhan X, Dixon MA, Liu S, Gros D, Korver W, Yonkovich S, Tomasevic N, Binnerts M, and Abo A. 2008. R-Spondin family members regulate the Wntpathway by a common mechanism. Mol Biol Cell 19 (6): 2588-2596.

Kinzler KW and Vogelstein B. 1996. Lessons from hereditary colorectal cancer. Cell 87 (2); 159-70.

Koduri V and Blacklow SC. 2007. Requirement for natively unstructured regions of mesoderm development candidate 2 in promoting low-density lipoprotein receptor-related protein 6 maturation. Biochemistry. 46 (22): 6570-6577.

Kohn AD and Moon RT. 2005. Wnt and calcium signaling: beta-catenin-independent pathways. Cell Calcium 38 (3-4): 439-446.

Kokkinos MI, Wafai R, Wong MK, Newgreen DF, Thompson EW, and Waltham M. 2007. Vimentin and epithelial-mesenchymal transition in human breast cancer-observations invitro and in vivo. Cells Tissues Organs 185 (1-3): 191-203.

Kokubu C, Heinzmann U, Kokubu T, Sakai N, Kubota T, Kawai M, Wahl MB, Galceran J, Grosschedl R, Ozono K, Imai K. 2004. Skeletal defects in ringelschwanz mutant mice reveal that Lrp6 is required for proper somitogenesis and osteogenesis. Development 131 (21): 5469-5480.

Kozlow W, and Guise TA. 2005. Breast cancer metastasis to bone: mechanisms of osteolysis and implications for therapy. J. Mammary Gland Biol Neoplasia 10 (2): 169-180.

Krishnan V, Bryant HU, and Macdougald OA. 2006. Regulation of bone mass by Wnt signaling. J Clin Invest 116 (5): 1202-1209.

Krupnik VE, Sharp JD, Jiang C, Robison K, Chickering TW, Amaravadi L, Brown DE, Guyot D, Mays G, Leiby K, Chang B, Duong T, Goodearl AD, Gearing DP, SokolSY, and 
McCarthy SA. 1999. Functional and structural diversity of the human Dickkopf genefamily. Gene 238 (2): 301-313.

Lacey DL, Timms E, Tan HL, Kelley MJ, Dunstan CR, Burgess T, Elliott R, Colombero A, Elliott G, Scully S, Hsu H, Sullivan J, Hawkins N, Davy E, Capparelli C, Eli A, Qian YX, Kaufman S, Sarosi I, Shalhoub V, Senaldi G, Guo J, Delaney J, Boyle WJ. 1998. Osteoprotegerin ligand is a cytokine that regulates osteoclast differentiation and activation. Cell 93 (2): 165-176.

Lane TF and Leder P. 1997. Wnt-10b directs hypermorphic development and transformation in mammary glands of male and female mice. Oncogene 15 (18): 2133-2144.

Lejeune S, Huguet EL, Hamby A, Poulsom R, and Harris AL. 1995. Wnt5a cloning, expression, and up-regulation in human primary breast cancers. Clin Cancer Res 1 (2): 215-222.

Leris AC, Roberts TR, Jiang WG, Newbold RF, and Mokbel K. 2005. WNT5A expression in human breast cancer. Anticancer Res 25 (2A): 731-734.

Li L, Mao J, Sun L, Liu W, and Wu D. 2002. Second cysteine-rich domain of Dickkopf-2 activates canonical Wnt signaling pathway via LRP-6 independently of dishevelled.J Biol Chem 277(8): 5977-5981.

Li X, Liu P, Liu W, Maye P, Zhang J, Zhang Y, Hurley M, Guo C, Boskey A, Sun L, Harris SE, Rowe DW, Ke HZ, and Wu D. 2005a. Dkk2 has a role in terminal osteoblast differentiation and mineralized matrix formation. Nat Genet 37 (9): 945-952.

Li X, Zhang Y, Kang H, Liu W, Liu P, Zhang J, Harris SE, and Wu D. 2005b. Sclerostin binds to LRP5/ 6 and antagonizes canonical Wnt signaling. J Biol Chem 280 (20): 1988319887.

Li Y, Chen J, Lu W, McCormick LM, Wang J, and Bu G. 2005c. Mesd binds to mature LDLreceptor-related protein-6 and antagonizes ligand binding. J Cell Sci 118 (22): 53055314.

Li Y, Lu W, He X, and Bu G. 2006a. Modulation of LRP6-mediated Wnt signaling by molecular chaperone Mesd. FEBS Lett 580 (22): 5423-5428.

Li J, Sarosi I, Cattley RC, Pretorius J, Asuncion F, Grisanti M, Morony S, Adamu S, Geng Z, Qiu W, Kostenuik P, Lacey DL, Simonet WS, Bolon B, Qian X, Shalhoub V, Ominsky MS, Zhu Ke H, Li X, and Richards WG. 2006b. Dkk1-mediated inhibition of Wnt signaling in bone results in osteopenia. Bone 39 (4): 754-766.

Li C, Chen H, Hu L, Xing Y, Sasaki T, Villosis MF, Li J, Nishita M, Minami Y, and Minoo P. 2008a. Ror2 modulates the canonical Wnt signaling in lung epithelial cells through cooperation with Fzd2. BMC Mol Biol 23: 9-11.

Li X, Lewis MT, Huang J, Gutierrez C, Osborne CK, Wu MF, Hilsenbeck SG, Pavlick A, Zhang X, Chamness GC, Wong H, Rosen J, Chang JC. 2008b. Intrinsic resistance of tumorigenic breast cancer cells to chemotherapy. J Natl Cancer Inst 100 (9): 672-679.

Li L, Hutchins BI, and Kalil K. 2009. Wnt5a induces simultaneous cortical axon outgrowth and repulsive axon guidance through distinct signaling mechanisms. J Neurosci 29 (18): 5873-5883.

Li Y, Lu W, King TD, Liu CC, Bijur GN, and Bu G. 2010. Dkk1 stabilizes Wnt co-receptor LRP6: implication for Wnt ligand-induced LRP6 down-regulation. PLoS One 5 (6): e11014. 
Licchesi JD, Van Neste L, Tiwari VK, Cope L, Lin X, Baylin SB, and Herman JG. 2010. Transcriptional regulation of Wnt inhibitory factor-1 by Miz-1/c-Myc. Oncogene 29 (44): 5923-5934.

Liepinsh E, Bányai L, Patthy L, and Otting G. 2006. NMR structure of the WIF domain of the human Wnt-inhibitory factor-1. J Mol Biol 357 (3): 942-950.

Lin K, Wang S, Julius MA, Kitajewski J, Moos M Jr, and Luyten FP. 1997. The cysteine-rich frizzled domain of Frzb-1 is required and sufficient for modulationof Wnt signaling. Proc Natl Acad Sci U S A 94 (21): 11196-11200.

Lindvall C, Evans NC, Zylstra CR, Li Y, Alexander CM, and Williams BO. 2006. The Wnt signaling receptor Lrp5 is required for mammary ductal stem cell activity andWnt1-induced tumorigenesis. J Biol Chem 281 (46): 35081-35087.

Lindvall C, Zylstra CR, Evans N, West RA, Dykema K, Furge KA, and Williams BO. 2009. The Wnt co-receptor Lrp6 is required for normal mouse mammary gland development. PLoSOne 4 (6): e5813.

Little RD, Carulli JP, Del Mastro RG, Dupuis J, Osborne M, Folz C, Manning SP, Swain PM, Zhao SC, Eustace B, Lappe MM, Spitzer L, Zweier S, Braunschweiger K, Benchekroun Y, Hu X, Adair R, Chee L, FitzGerald MG, Tulig C, Caruso A, Tzellas N, Bawa A, Franklin B, McGuire S, Nogues X, Gong G, Allen KM, Anisowicz A, Morales AJ, Lomedico PT, Recker SM, Van Eerdewegh P, Recker RR, and Johnson ML. 2002. A mutation in the LDL receptor-related protein 5 gene results in the autosomal dominant high-bone-mass trait. Am J Hum Genet 70 (1): 11-19.

Liu G, Bafico A, Harris VK, and Aaronson SA. 2003. A novel mechanism for Wnt activation of canonical signaling through the LRP6 receptor. Mol Cell Biol 23 916): 5825 -5835.

Liu Y, Rubin B, Bodine PV, and Billiard J. 2008. Wnt5a induces homodimerization andactivation of Ror2 receptor tyrosine kinase. J Cell Biochem 105 (2): 497-502.

Liu CC, Pearson C, and Bu G. 2009. Cooperative folding and ligand-binding properties of LRP6 beta-propeller domains. J Biol Chem 284 (22): 15299-15307.

Liu CC, Prior J, Piwnica-Worms D, and Bu G. 2010. LRP6 overexpression defines a class of breast cancer subtype and is a target for therapy. Proc Natl Acad Sci U S A 107 (11): 5136-5141.

Lee JL, Chang CJ, Chueh LL, and Lin CT. 2003. Expression of secreted frizzled-related protein 2 in a primary canine mammary tumor cell line: a candidate tumor markerfor mammary tumor cells. In Vitro Cell Dev Biol Anim 39 (5-6): 221-227.

Lee AY, He B, You L, Dadfarmay S, Xu Z, Mazieres J, Mikami I, McCormick F, and Jablons DM. 2004. Expression of the secreted frizzled-related protein gene family is downregulated in human mesothelioma. Oncogene 23 (39): 6672-6676.

Ling L, Nurcombe V, and Cool SM. 2008. Wnt signaling controls the fate of mesenchymal stem cells. Gene 433 (1-2): 1-7.

Lo PK, Mehrotra J, D'Costa A, Fackler MJ, Garrett-Mayer E, Argani P, and Sukumar S. 2006. Epigenetic suppression of secreted frizzled related protein 1 (SFRP1) expression in human breast cancer. Cancer Biol Ther 5 (3): 281-286.

López-Knowles E, Zardawi SJ, McNeil CM, Millar EK, Crea P, Musgrove EA, Sutherland RL, and O'Toole SA. 2010. Cytoplasmic localization of beta-catenin is a marker of poor outcome in breast cancer patients. Cancer Epidemiol Biomarkers Prev 19 (1): 301309. 
López-Novoa JM and Nieto MA. 2009. Inflammation and EMT: an alliance towards organ fibrosis and cancer progression. EMBO Mol Med 1 (6-7): 303-314.

Lowther W, Wiley K, Smith GH, and Callahan R. 2005. A new common integration site, Int7, for the mouse mammary tumor virus in mouse mammary tumors identifies a gene whoseproduct has furin-like and thrombospondin-like sequences. J Virol 79 (15): 10093-10096.

Lu W, Yamamoto V, Ortega B, and Baltimore D. 2004. Mammalian Ryk is a Wnt coreceptor required for stimulation of neurite outgrowth. Cell 119 (1): 97-108.

MacDonald BT, Tamai K, and He X. 2009. Wnt/beta-catenin signaling: components, mechanisms, and diseases. Dev Cell 17 (1): 9-26.

Mao J, Wang J, Liu B, Pan W, Farr GH 3rd, Flynn C, Yuan H, Takada S, Kimelman D, Li L, and Wu D. 2001a. Low-density lipoprotein receptor-related protein-5 binds to Axin and regulates the canonical Wnt signaling pathway. Mol Cell 7 (4): 801-809.

Mao B, Wu W, Li Y, Hoppe D, Stannek P, Glinka A, and Niehrs C. 2001b. LDL-receptorrelated protein 6 is a receptor for Dickkopf proteins. Nature 411 (6835): 321-325.

Mao B, Wu W, Davidson G, Marhold J, Li M, Mechler BM, Delius H, Hoppe D, Stannek P, Walter C, Glinka A, and Niehrs C. 2002. Kremen proteins are Dickkopf receptorsthat regulate Wnt/beta-catenin signalling. Nature 417 (6889): 664-667.

Mao B and Niehrs C. 2003. Kremen2 modulates Dickkopf2 activity during Wnt/LRP6 signaling. Gene 302 (1-2): 179-183.

Magni M, Shammah S, Schiró R, Mellado W, Dalla-Favera R, and Gianni AM. 1996. Induction of cyclophosphamide-resistance by aldehyde-dehydrogenase gene transfer. Blood 87 (3): 1097-1103.

Mann B, Gelos M, Siedow A, Hanski ML, Gratchev A, Ilyas M, Bodmer WF, Moyer MP, Riecken EO, Buhr HJ, and Hanski C. 1999. Target genes of beta-catenin-Tcellfactor/lymphoid-enhancer-factor signaling in human colorectal carcinomas. Proc Natl Acad Sci U S A 96 (4): 1603-1608.

Martin TA, Goyal A, Watkins G, and Jiang WG. 2005. Expression of the transcription factors snail, slug, and twist and their clinical significance in human breast cancer. Ann Surg Oncol 12 (6): 488-496.

Matsuda Y, Schlange T, Oakeley EJ, Boulay A, and Hynes NE. 2009. WNT signaling enhances breast cancer cell motility and blockade of the WNT pathway by sFRP1 suppressesMDA-MB-231 xenograft growth. Breast Cancer Res 11(3): R32.

Medrek C, Landberg G, Andersson T, and Leandersson K. 2009. Wnt-5a-CKI\{alpha\} signaling promotes beta\}-catenin/E-cadherin complex formation and intercellular adhesion in human breast epithelial cells. J Biol Chem 284 (16): 10968-10979.

Micalizzi DS, Farabaugh SM, and Ford HL. 2010. Epithelial-mesenchymal transition in cancer: parallels between normal development and tumor progression. J MammaryGland Biol Neoplasia 15 (2): 117-134.

Mikels AJ and Nusse R. 2006. Purified Wnt5a protein activates or inhibits beta-catenin-TCF signaling depending on receptor context. PLoS Biol 4 (4): e115.

Minami Y, Oishi I, Endo M, and Nishita M. 2010. Ror-family receptor tyrosine kinases in noncanonical Wnt signaling: their implications in developmental morphogenesis and human diseases. Dev Dyn 239 (1): 1-15. 
Milovanovic T, Planutis K, Nguyen A, Marsh JL, Lin F, Hope C, and Holcombe RF. 2004. Expression of Wnt genes and frizzled 1 and 2 receptors in normal breast epithelium and infiltrating breast carcinoma. Int J Oncol 25 (5): 1337-1342.

Moody SE, Perez D, Pan TC, Sarkisian CJ, Portocarrero CP, Sterner CJ, Notorfrancesco KL, Cardiff RD, and Chodosh LA. 2005. The transcriptional repressor Snail promotes mammary tumor recurrence. Cancer Cell 8 (3): 197-209.

Morimoto K, Kim SJ, Tanei T, Shimazu K, Tanji Y, Taguchi T, Tamaki Y, Terada N, and Noguchi S. 2009. Stem cell marker aldehyde dehydrogenase 1-positive breast cancersare characterized by negative estrogen receptor, positive human epidermal growth factor receptor type 2, and high Ki67 expression. Cancer Sci 100 (6): 10621068 .

Morvan F, Boulukos K, Clément-Lacroix P, Roman Roman S, Suc-Royer I, Vayssière B, Ammann P, Martin P, Pinho S, Pognonec P, Mollat P, Niehrs C, Baron R, Rawadi G. 2006. Deletion of a single allele of the Dkk1 gene leads to an increase in bone formation and bone mass. J Bone Miner Res 21 (6): 934-945.

Mundy GR. 2002. Metastasis to bone: causes, consequences and therapeutic opportunities. Nat Rev Cancer 2: 584-593.

Nam JS, Turcotte TJ, and Yoon JK. 2006. Dynamic expression of R-spondin family genes in mouse development. Gene Expr Patterns 7 (3): 306-312.

Nemeth MJ, Topol L, Anderson SM, Yang Y, and Bodine DM. 2007. Wnt5a inhibits canonical Wnt signaling in hematopoietic stem cells and enhances repopulation. Proc NatlAcad Sci U S A 104 (39): 15436-15441.

Niehrs C. 2006. Function and biological roles of the Dickkopf family of Wnt modulators. Oncogene 25 (57): 7469-7481.

Niida A, Hiroko T, Kasai M, Furukawa Y, Nakamura Y, Suzuki Y, Sugano S, Akiyama T. 2004. DKK1, a negative regulator of Wnt signaling, is a target of the betacatenin/TCF pathway. Oncogene 23 (52): 8520-8526.

Nguyen NP, Almeida FS, Chi A, Nguyen LM, Cohen D, Karlsson U, and Vinh-Hung V. 2010. Molecular biology of breast cancer stem cells: potential clinical applications. Cancer Treat Rev 36 (6): 485-491.

Nusse R, Brown A, Papkoff J, Scambler P, Shackleford G, McMahon A, Moon R, and Varmus H. 1991. A new nomenclature for int-1 and related genes: the Wnt gene family. Cell 64 (2): 231.

Nusse R and Varmus HE. 1982. Many tumors induced by the mouse mammary tumor virus contain a provirus integrated in the same region of the host genome. Cell 31 (1): 99109.

Oloumi A, Maidan M, Lock FE, Tearle H, McKinney S, Muller WJ, Aparicio SA, and Dedhar S. 2010. Cooperative signaling between Wnt1 and integrin-linked kinase induces accelerated breast tumor development. Breast Cancer Res 12 (3): R38.

Ott SM. 2005. Sclerostin and Wnt signaling--the pathway to bone strength. J Clin Endocrinol Metab 90 (12): 6741-6743.

Patthy L. 2000. The WIF module. Trends Biochem Sci 25 (1): 12-23.

Peters G, Brookes S, Smith R, and Dickson C. 1983. Tumorigenesis by mouse mammary tumor virus: evidence for a common region for provirus integration in mammary tumors. Cell 33 (2): 369-377. 
Pinson KI, Brennan J, Monkley S, Avery BJ, and Skarnes WC. 2000. An LDL-receptor-related protein mediates Wnt signalling in mice. Nature 407 (6803): 535-538.

Pinzone JJ, Hall BM, Thudi NK, Vonau M, Qiang YW, Rosol TJ, and Shaughnessy JD Jr. 2009. The role of Dickkopf-1 in bone development, homeostasis, and disease. Blood 113 (3): 517-525.

Rattner A, Hsieh JC, Smallwood PM, Gilbert DJ, Copeland NG, Jenkins NA, and Nathans J. 1997. A family of secreted proteins contains homology to the cysteine-rich ligandbinding domain of frizzled receptors. Proc Natl Acad Sci U S A 94 (7): 2859-2863.

Resetkova E, Reis-Filho JS, Jain RK, Mehta R, Thorat MA, Nakshatri H, and Badve S. 2010. Prognostic impact of ALDH1 in breast cancer: a story of stem cells and tumormicroenvironment. Breast Cancer Res Treat 123 (1): 97-108.

Rijsewijk F, Schuermann M, Wagenaar E, Parren P, Weigel D, and Nusse R. 1987. The Drosophila homolog of the mouse mammary oncogene int-1 is identical to the segment polarity gene wingless. Cell 50 (4): 649-657.

Roarty K, Baxley SE, Crowley MR, Frost AR, and Serra R. 2009. Loss of TGF-beta or Wnt5a results in an increase in Wnt/beta-catenin activity and redirects mammary tumour phenotype. Breast Cancer Res 11 (2): R19.

Roarty K and Serra R. 2007. Wnt5a is required for proper mammary gland development and TGF-beta-mediated inhibition of ductal growth. Development 134 (21): 3929-3939.

Roodman GD. 2004. Mechanisms of bone metastasis. N Engl J Med 350: 1655-1664.

Saitoh T, Mine T, and Katoh M. 2002. Up-regulation of Frizzled-10 (FZD10) by beta-estradiol in MCF-7 cells and by retinoic acid in NT2 cells. Int J Oncol 20 (1): 117-120.

Schulte G. 2010. International Union of Basic and Clinical Pharmacology. LXXX. The class Frizzled receptors. Pharmacol Rev 62 (4): 632-667.

Seaberg RM and van der Kooy D. 2003. Stem and progenitor cells: the premature desertion of rigorous definitions. Trends Neurosci 26 (3): 125-131.

Seifert JR and Mlodzik M. 2007. Frizzled/PCP signalling: a conserved mechanism regulating cell polarity and directed motility. Nat Rev Genet 8 (2): 126-138.

Sell S. 2004. Stem cell origin of cancer and differentiation therapy. Crit Rev Oncol Hematol 51 (1): 1-28.

Semënov MV, Tamai K, Brott BK, Kühl M, Sokol S, and He X. 2001. Head inducer Dickkopf1 is a ligand for Wnt coreceptor LRP6. Curr Biol 11 (12): 951-961.

Semënov M, Tamai K, and He X. 2005. SOST is a ligand for LRP5/LRP6 and a Wnt signaling inhibitor. J Biol Chem 280 (29): 26770-26775.

Semenov MV and He X. 2006. LRP5 mutations linked to high bone mass diseases cause reduced LRP5 binding and inhibition by SOST. J Biol Chem 281 (50): 38276-3884.

Sheridan C, Kishimoto H, Fuchs RK, Mehrotra S, Bhat-Nakshatri P, Turner CH, Goulet R Jr, Badve S, and Nakshatri H. 2006. CD44+/CD24- breast cancer cells exhibitenhanced invasive properties: an early step necessary for metastasis. Breast Cancer Res 8 (5): R59.

Shimizu H, Julius MA, Giarré M, Zheng Z, Brown AM, and Kitajewski J. 1997. Transformation by Wnt family proteins correlates with regulation of beta-catenin. Cell Growth Differ 8 (12): 1349-1358.

Shtutman M, Zhurinsky J, Simcha I, Albanese C, D'Amico M, Pestell R, and Ben-Ze'ev A. 1999. The cyclin D1 gene is a target of the beta-catenin/LEF-1 pathway. Proc NatlAcad Sci U S A 96 (10): 5522-5527. 
Shulewitz M, Soloviev I, Wu T, Koeppen H, Polakis P, and Sakanaka C. 2006. Repressor roles for TCF-4 and Sfrp1 in Wnt signaling in breast cancer. Oncogene 25 (31): 43614369 .

Simonet WS, Lacey DL, Dunstan CR, Kelley M, Chang MS, Lüthy R, Nguyen HQ, Wooden S, Bennett L, Boone T, Shimamoto G, DeRose M, Elliott R, Colombero A, Tan HL, Trail G, Sullivan J, Davy E, Bucay N, Renshaw-Gegg L, Hughes TM, Hill D, Pattison W, Campbell P, Sander S, Van G, Tarpley J, Derby P, Lee R, and Boyle WJ. 1997. Osteoprotegerin: A novel secreted protein involved in the regulation of bone density. Cell 89 (2): 309-319.

Smallwood PM, Williams J, Xu Q, Leahy DJ, and Nathans J. 2007. Mutational analysis of Norrin-Frizzled4 recognition. J Biol Chem 282 (6): 4057-4068.

Sophos NA and Vasiliou V. 2002. Aldehyde dehydrogenase gene superfamily: the 2002 update. Chem Biol Interact 143-144: 5-22.

Steinert PM and Roop DR. 1988. Molecular and cellular biology of intermediate filaments. Annu Rev Biochem 57: 593-625.

Suda T, Takahashi N, Udagawa N, Jimi E, Gillespie MT, and Martin TJ. 1999. Modulation of osteoclast differentiation and function by the new members of the tumor necrosis factor receptor and ligand families. Endocr Rev 20 (3): 345-357.

Surmann-Schmitt C, Widmann N, Dietz U, Saeger B, Eitzinger N, Nakamura Y, Rattel M, Latham R, Hartmann C, von der Mark H, Schett G, von der Mark K, and StockM. 2009. Wif-1 is expressed at cartilage-mesenchyme interfaces and impedes Wnt3amediated inhibition of chondrogenesis. J Cell Sci 122 (Pt 20): 3627-3637.

Suzuki H, Toyota M, Carraway H, Gabrielson E, Ohmura T, Fujikane T, Nishikawa N, Sogabe Y, Nojima M, Sonoda T, Mori M, Hirata K, Imai K, Shinomura Y, Baylin SB, and Tokino T. 2008. Frequent epigenetic inactivation of Wnt antagonist genes in breast cancer. Br J Cancer 98 (6): 1147-1156.

Takada R, Satomi Y, Kurata T, Ueno N, Norioka S, Kondoh H, Takao T, and Takada S. 2006. Monounsaturated fatty acid modification of Wnt protein: its role in Wntsecretion. Dev Cell 11 (6): 791-801.

Tamai K, Semenov M, Kato Y, Spokony R, Liu C, Katsuyama Y, Hess F, Saint-Jeannet JP, and He X. 2000. LDL-receptor-related proteins in Wnt signal transduction. Nature. 407 (6803): 530-535.

Tamai K, Zeng X, Liu C, Zhang X, Harada Y, Chang Z, and He X. 2004. A mechanism for Wnt coreceptor activation. Mol Cell 13 (1): 149-156.

Tanei T, Morimoto K, Shimazu K, Kim SJ, Tanji Y, Taguchi T, Tamaki Y, and Noguchi S. 2009. Association of breast cancer stem cells identified by aldehyde dehydrogenase 1expression with resistance to sequential Paclitaxel and epirubicin-based chemotherapy for breast cancers. Clin Cancer Res 15 (12): 4234-4241.

Teissedre B, Pinderhughes A, Incassati A, Hatsell SJ, Hiremath M, and Cowin P. 2009. MMTV-Wnt1 and -DeltaN89beta-catenin induce canonical signaling in distinctprogenitors and differentially activate Hedgehog signaling within mammary tumors. PLoS One 4 (2): e4537.

Tetsu O and McCormick F. 1999. Beta-catenin regulates expression of cyclin D1 in colon carcinoma cells. Nature 398 (6726): 422-426.

Ting AH, McGarvey KM, and Baylin SB. 2006. The cancer epigenome--components and functional correlates. Genes Dev 20 (23): 3215-3231. 
Tolwinski NS, Wehrli M, Rives A, Erdeniz N, DiNardo S, and Wieschaus E. 2003. Wg/Wnt signal can be transmitted through arrow/LRP5,6 and Axin independently of Zw3/Gsk3beta activity. Dev Cell 4 (3): 407-418.

Topol L, Jiang X, Choi H, Garrett-Beal L, Carolan PJ, and Yang Y. 2003. Wnt-5a inhibits the canonical Wnt pathway by promoting GSK-3-independent beta-catenin degradation. J Cell Biol 162 (5): 899-908.

Tsukamoto AS, Grosschedl R, Guzman RC, Parslow T, and Varmus HE. 1988. Expression of theint-1 gene in transgenic mice is associated with mammary gland hyperplasia and adenocarcinomas in male and female mice. Cell 55 (4): 619-625.

Ugolini F, Adélaïde J, Charafe-Jauffret E, Nguyen C, Jacquemier J, Jordan B, Birnbaum D, and Pébusque MJ. 1999. Differential expression assay of chromosome arm 8p genesidentifies Frizzled-related (FRP1/FRZB) and Fibroblast Growth Factor Receptor 1 (FGFR1) as candidate breast cancer genes. Oncogene 18 (10): 1903-1910.

Ugolini F, Charafe-Jauffret E, Bardou VJ, Geneix J, Adélaïde J, Labat-Moleur F, PenaultLlorca F, Longy M, Jacquemier J, Birnbaum D, and Pébusque MJ. 2001. WNT pathway and mammary carcinogenesis: loss of expression of candidate tumor suppressor gene SFRP1 in most invasive carcinomas except of the medullary type. Oncogene 20 (41): 5810-5817.

Uren A, Reichsman F, Anest V, Taylor WG, Muraiso K, Bottaro DP, Cumberledge S, and Rubin JS. 2000. Secreted frizzled-related protein-1 binds directly to Wingless and is abiphasic modulator of Wnt signaling. J Biol Chem 275 (6): 4374-4382.

Van Meurs JB, Rivadeneira F, Jhamai M, Hugens W, Hofman A, van Leeuwen JP, Pols HA, and Uitterlinden AG. 2006. Common genetic variation of the low-density lipoprotein receptor-related protein 5 and 6 genes determines fracture risk in elderly white men. J Bone Miner Res 21 (1): 141-150.

Van Wesenbeeck L, Cleiren E, Gram J, Beals RK, Bénichou O, Scopelliti D, Key L, Renton T, Bartels C, Gong Y, Warman ML, De Vernejoul MC, Bollerslev J, and Van Hul W. 2003. Six novel missense mutations in the LDL receptor-related protein 5 (LRP5) gene in different conditions with an increased bone density. Am J Hum Genet 72 (3): 763-771.

Veeck J, Geisler C, Noetzel E, Alkaya S, Hartmann A, Knüchel R, and Dahl E. 2008. Epigenetic inactivation of the secreted frizzled-related protein-5 (SFRP5) genein human breast cancer is associated with unfavorable prognosis. Carcinogenesis 29 (5): 991-998.

Veeck J, Niederacher D, An H, Klopocki E, Wiesmann F, Betz B, Galm O, Camara O, Dürst M, Kristiansen G, Huszka C, Knüchel R, and Dahl E. 2006. Aberrant methylation ofthe Wnt antagonist SFRP1 in breast cancer is associated with unfavourable prognosis. Oncogene 25 (24): 3479-3488.

Veeck J, Noetzel E, Bektas N, Jost E, Hartmann A, Knüchel R, and Dahl E. 2008. Promoter hypermethylation of the SFRP2 gene is a high-frequent alteration and tumorspecific epigenetic marker in human breast cancer. Mol Cancer 7: 83.

Veeck J and Esteller M. 2010. Breast cancer epigenetics: from DNA methylation to microRNAs. J Mammary Gland Biol Neoplasia 15 (1): 5-17.

Vinson CR and Adler PN. 1987. Directional non-cell autonomy and the transmission of polarity information by the frizzled gene of Drosophila. Nature 329 (6139): 549-551. 
Vinson CR, Conover S, and Adler PN. 1989. A Drosophila tissue polarity locus encodes a protein containing seven potential transmembrane domains. Nature 338 (6212): 6364.

Voorzanger-Rousselot N, Goehrig D, Journe F, Doriath V, Body JJ, Clézardin P, and Garnero P. 2007. Increased Dickkopf-1 expression in breast cancer bone metastases. $\mathrm{Br} \mathrm{J}$ Cancer 97 (7): 964-970.

Wang FS, Ko JY, Lin CL, Wu HL, Ke HJ, and Tai PJ. 2007a. Knocking down dickkopf-1 alleviates estrogen deficiency induction of bone loss. A histomorphological study in ovariectomized rats. Bone 40 (2): 485-492

Wang Y and Nathans J. 2007b. Tissue/planar cell polarity in vertebrates: new insights and new questions. Development 134 (4): 647-658.

Wang PS, Chou FS, Bloomston M, Vonau MS, Saji M, Espinosa A, and Pinzone JJ. 2009. Thiazolidinediones downregulate Wnt/beta-catenin signaling via multiplemechanisms in breast cancer cells. J Surg Res 153 (2): 210-216.

Wehrli M, Dougan ST, Caldwell K, O'Keefe L, Schwartz S, Vaizel-Ohayon D, Schejter E, Tomlinson A, and DiNardo S. 2000. Arrow encodes an LDL-receptor-related protein essential for Wingless signaling. Nature 407 (6803): 527-530.

Wei Q, Yokota C, Semenov MV, Doble B, Woodgett J, and He X. 2007. R-spondin1 is a high affinity ligand for LRP6 and induces LRP6 phosphorylation and beta-catenin signaling. J Biol Chem 282 (21): 15903-15911.

Welm BE, Tepera SB, Venezia T, Graubert TA, Rosen JM, and Goodell MA. 2002. Sca-1(pos) cells in the mouse mammary gland represent an enriched progenitor cell population. Dev Biol 245 (1): 42-56.

Wielenga VJ, Smits R, Korinek V, Smit L, Kielman M, Fodde R, Clevers H, and Pals ST. 1999. Expression of CD44 in Apc and Tcf mutant mice implies regulation by the WNTpathway. Am J Pathol 154 (2): 515-523.

Wielenga VJ, van der Neut R, Offerhaus GJ, and Pals ST. 2000. CD44 glycoproteins in colorectal cancer: expression, function, and prognostic value. Adv Cancer Res 77: 169-187.

Wissmann C, Wild PJ, Kaiser S, Roepcke S, Stoehr R, Woenckhaus M, Kristiansen G, Hsieh JC, Hofstaedter F, Hartmann A, Knuechel R, Rosenthal A, and Pilarsky C. 2003. WIF1, a component of the Wnt pathway, is down-regulated in prostate, breast, lung, and bladder cancer. J Pathol 201 (2): 204-212.

Wong GT, Gavin BJ, and McMahon AP. 1994. Differential transformation of mammary epithelial cells by Wnt genes. Mol Cell Biol 14 (9): 6278-6286.

Woodward WA, Chen MS, Behbod F, Alfaro MP, Buchholz TA, and Rosen JM. 2007. WNT/beta-catenin mediates radiation resistance of mouse mammary progenitor cells. Proc Natl Acad Sci U S A. 104 (2): 618-623.

Wu W, Glinka A, Delius H, and Niehrs C. 2000. Mutual antagonism between dickkopf1 and dickkopf2 regulates Wnt/beta-catenin signalling. Curr Biol 10 (24): 1611-1614.

Xu Q, Wang Y, Dabdoub A, Smallwood PM, Williams J, Woods C, Kelley MW, Jiang L, Tasman W, Zhang K, and Nathans J. 2004. Vascular development in the retina and innerear: control by Norrin and Frizzled-4, a high-affinity ligand-receptor pair. Cell 116 (6): 883-895. 
Yamamoto S, Nishimura O, Misaki K, Nishita M, Minami Y, Yonemura S, Tarui H, and Sasaki H. 2008. Cthrc1 selectively activates the planar cell polarity pathway of Wnt signaling by stabilizing the Wnt-receptor complex. Dev Cell 15 (1): 23-36.

Yasuda H, Shima N, Nakagawa N, Yamaguchi K, Kinosaki M, Mochizuki S, Tomoyasu A, Yano K, Goto M, Murakami A, Tsuda E, Morinaga T, Higashio K, Udagawa N, Takahashi N, and Suda T. 1998. Osteoclast differentiation factor is a ligand for osteoprotegerin/osteoclastogenesis-inhibitory factor and is identical to TRANCE/RANKL. Proc Natl Acad Sci. U S A 95 (7): 3597-3602.

Yoneda T. 1998. Cellular and molecular mechanisms of breast and prostate cancer metastasis to bone. Eur J Cancer 34 (2): 240-245.

Yook JI, Li XY, Ota I, Hu C, Kim HS, Kim NH, Cha SY, Ryu JK, Choi YJ, Kim J, Fearon ER, and Weiss SJ. 2006. A Wnt-Axin2-GSK3beta cascade regulates Snail1 activity inbreast cancer cells. Nat Cell Biol 8 (12): 1398-1406.

Yoshida A, Rzhetsky A, Hsu LC, and Chang C. 1998. Human aldehyde dehydrogenase gene family. Eur J Biochem 251 (3): 549-557.

Yu HM, Jerchow B, Sheu TJ, Liu B, Costantini F, Puzas JE, Birchmeier W, and Hsu W. 2005. The role of Axin2 in calvarial morphogenesis and craniosynostosis. Development 132 (8): 1995-2005.

Zardawi SJ, O'Toole SA, Sutherland RL, and Musgrove EA. 2009. Dysregulation of Hedgehog, Wnt and Notch signalling pathways in breast cancer. Histol Histopathol 24 (3): 385-398.

Zeng X, Tamai K, Doble B, Li S, Huang H, Habas R, Okamura H, Woodgett J, and He X. 2005. A dual-kinase mechanism for Wnt co-receptor phosphorylation and activation. Nature 438 (7069): 873-877.

Zhang Y, Wang Y, Li X, Zhang J, Mao J, Li Z, Zheng J, Li L, Harris S, and Wu D. 2004. The LRP5 high-bone-mass G171V mutation disrupts LRP5 interaction with Mesd. Mol Cell Biol 24 (11): 4677-4684.

Zhang J, Li Y, Liu Q, Lu W, and Bu G. 2010. Wnt signaling activation and mammary gland hyperplasia in MMTV-LRP6 transgenic mice: implication for breast cancertumorigenesis. Oncogene 29 (4): 539-549. 


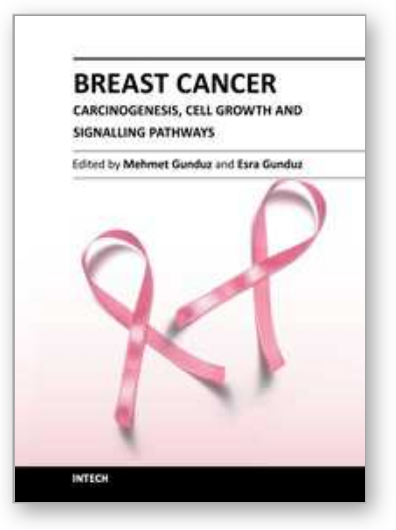

\author{
Breast Cancer - Carcinogenesis, Cell Growth and Signalling \\ Pathways \\ Edited by Prof. Mehmet Gunduz
}

ISBN 978-953-307-714-7

Hard cover, 732 pages

Publisher InTech

Published online 30, November, 2011

Published in print edition November, 2011

Cancer is the leading cause of death in most countries and its consequences result in huge economic, social and psychological burden. Breast cancer is the most frequently diagnosed cancer type and the leading cause of cancer death among females. In this book, we discussed various aspects of breast cancer carcinogenesis from clinics to its hormone-based as well as genetic-based etiologies for this deadly cancer. We hope that this book will contribute to the development of novel diagnostic as well as therapeutic approaches.

\title{
How to reference
}

In order to correctly reference this scholarly work, feel free to copy and paste the following:

Taj D. King and Yonghe Li (2011). Dysregulation of Wnt Signaling in Breast Cancer, Breast Cancer Carcinogenesis, Cell Growth and Signalling Pathways, Prof. Mehmet Gunduz (Ed.), ISBN: 978-953-307-714-7, InTech, Available from: http://www.intechopen.com/books/breast-cancer-carcinogenesis-cell-growth-andsignalling-pathways/dysregulation-of-wnt-signaling-in-breast-cancer

\section{INTECH}

open science | open minds

\section{InTech Europe}

University Campus STeP Ri

Slavka Krautzeka 83/A

51000 Rijeka, Croatia

Phone: +385 (51) 770447

Fax: +385 (51) 686166

www.intechopen.com

\section{InTech China}

Unit 405, Office Block, Hotel Equatorial Shanghai

No.65, Yan An Road (West), Shanghai, 200040, China 中国上海市延安西路65号上海国际贵都大饭店办公楼 405 单元

Phone: +86-21-62489820

Fax: $+86-21-62489821$ 
(C) 2011 The Author(s). Licensee IntechOpen. This is an open access article distributed under the terms of the Creative Commons Attribution 3.0 License, which permits unrestricted use, distribution, and reproduction in any medium, provided the original work is properly cited. 